\title{
Introduction: Re-examining Criminal Process Through the Lens of Integrity
}

PAUL ROBERTS, JILL HUNTER, SIMON NM YOUNG AND DAVID DIXON

\section{Methodological Integrity}

This book explores the relationship between integrity and criminal process. By 'criminal process' we mean, roughly speaking, the institutions, procedures and practices constituting official responses to suspected criminal wrongdoing, encompassing criminal investigations, prosecutions, trials, appeals and extraordinary post-conviction procedures. We do not extend our analysis to 'the penal system' and the treatment of convicted offenders, largely on pragmatic rather than theoretical grounds. The book's central thesis is that 'integrity' offers a powerful conceptual lens through which the criminal process in its entirety, or selected phases or aspects of it, can be viewed and critically re-examined. Our general approach could in principle be extended to penality ${ }^{1}$ at large, but we had to stop somewhere to keep the volume within reasonable bounds, and adjudication marks a natural temporal breakpoint, distinguishing the participation of suspects, victims, witnesses and the accused in the investigative process and at trial from the treatment of convicted offenders in the penal system. ${ }^{2}$

This study is properly characterised as exploratory for at least two, mutually reinforcing reasons. First, as a themed collection of essays by 17 authors, each with their own theoretical preferences and perspectives, the analyses, discussions and arguments presented in the following chapters are necessarily somewhat open-ended, idiosyncratic and disputatious. More fundamentally, however, the juxtaposition between integrity and criminal process is relatively novel and unexamined. To the best of our knowledge, this is the first work to attempt anything like a systematic exploration. With this in mind, our primary objective in breaking new conceptual ground is to stimulate further discussion and critical reflection,

${ }^{1}$ Garland's handy neologism encapsulating 'the whole of the penal complex, including its laws, sanctions, institutions, and practices and its discourses, symbols, rituals, and performances'. See D Garland, 'Penality and the Penal State' (2013) 51 Criminology 475; D Garland, Punishment and Modern Society (Oxford, Clarendon Press, 1990).

2 The natural break between criminal process and the penal system is institutionally reinforced in common law jurisdictions, inasmuch as common law courts do not supervise the imposition of punishment (beyond generic powers of judicial review applicable to all administrative exercises of public power) in the direct way that, for example, German courts do. See M Bohlander, Principles of German Criminal Procedure (Oxford, Hart Publishing, 2012) ch 7. 
rather than purporting to supply the last word on the topic-as preposterous as that would be, given the complexity and richness of our subject-matter. The pluralistic, open-ended, productively argumentative format of an edited collection is eminently well suited to these programmatic objectives.

Our methodology is also pluralistic in a second, more theoretical sense. Surveying existing disciplinary literatures, and trying to begin without too many theoretical stipulations or preconceptions, there are many different ways and means in which one could conceivably attempt to conceptualise, analyse and debate criminal process. Some approaches are purely descriptive, empirical or more broadly factual, whilst others adopt avowedly normative, idealistic, ${ }^{3}$ moral or political perspectives. Many accounts blend descriptive and normative elements with varying levels of clarity and illumination (not all of them are optimally explicit about which element of their account is which). Criminal process is often conceptualised holistically in terms of one or more comprehensive 'models'. Herbert Packer's 'due process' and 'crime control' dyad is perhaps the most celebrated and influential process model in the Anglo-American literature, ${ }^{4}$ but there are many other alternatives and variations. ${ }^{5}$ Process modelling is continuously updated to accommodate significant developments in criminal justice policy and practice, as we see, for example, in the fairly recent emergence of a 'human rights model' of criminal process-a conceptualisation that would never have occurred to criminal law theorists of Packer's vintage. Comparative perspectives introduce further layers of complexity and sophistication in conceptual modelling. In substantive law (including criminal law), comparative lawyers routinely distinguish 'common law' from civilian or Romanist jurisprudence, concepts and approaches, treating jurisdiction and institutional history as their touchstones. ${ }^{6}$ In criminal procedure, the more familiar contrast is between 'adversarial' and 'inquisitorial' systems. ${ }^{7}$ Each of these primary comparative vectors can be manipulated and worked up into more sophisticated theories, for example by populating the globe with multiple 'families of law'8 ${ }^{38}$ by combining

\footnotetext{
3 See RA Duff, 'Retributive Punishment-Ideals and Actualities' (1991) 25 Israel Law Review 422.

4 HL Packer, 'Two Models of the Criminal Process' (1964) 113 University of Pennsylvania Law Review 1; HL Packer, The Limits of the Criminal Sanction (Palo Alto CA, Stanford University Press, 1969).

5 Prominently including MR Damaška, The Faces of Justice and State Authority (New Haven CT, Yale University Press, 1986). See further, P Roberts, 'Faces of Justice Adrift? Damaška's Comparative Method and the Future of Common Law Evidence' in J Jackson, M Langer and P Tillers (eds), Crime, Procedure and Evidence in a Comparative and International Context (Oxford, Hart Publishing, 2008); A Ashworth and M Redmayne, The Criminal Process, 4th edn (Oxford, Oxford University Press, 2010) chs 1-3; A Sanders, R Young and M Burton, Criminal Justice, 4th edn (Oxford, Oxford University Press, 2010) ch 1; N Lacey, 'Making Sense of Criminal Justice' in N Lacey (ed), A Reader on Criminal Justice (Oxford, Oxford University Press, 1994).

${ }^{6}$ LE Chiesa, 'Comparative Criminal Law' in MD Dubber and T Hörnle (eds), The Oxford Handbook of Criminal Law (Oxford, Oxford University Press, 2014).

7 M Langer, 'The Long Shadow of the Adversarial and Inquisitorial Categories' in Dubber and Hörnle, ibid; S Field, 'Fair Trials and Procedural Traditions in Europe' (2009) 29 Oxford Journal of Legal Studies 365; J McEwan, 'Ritual, Fairness and Truth: The Adversarial and Inquisitorial Models of Criminal Trial' in A Duff, L Farmer, S Marshall and V Tadros (eds), The Trial on Trial Volume I: Truth and Due Process (Oxford, Hart Publishing, 2004). For imaginative metaphorical extensions, see E Grande, 'Dances of Criminal Justice: Thoughts on Systemic Differences and the Search for the Truth'; and R Lempert, 'Anglo-American and Continental Systems: Marsupials and Mammals of the Law', both in Jackson et al (eds), above n 5; WT Pizzi, 'Soccer, Football and Trial Systems' (1995) 1 Columbia Journal of European Law 369.

${ }^{8}$ HP Glenn, 'Comparative Legal Families and Comparative Legal Traditions' in $M$ Reimann and R Zimmermann (eds), The Oxford Handbook of Comparative Law (Oxford, Oxford University Press, 2006); K Zweigert and H Kötz, An Introduction to Comparative Law, 3rd edn, T Weir trans (Oxford, Oxford University Press, 1998) Part I.
} 
adversarial and inquisitorial elements with other political, socio-economic or cultural factors into a galaxy of procedural hybrids. ${ }^{9}$ The advent of international criminal proceedings and the pervasive contemporary influences of globalisation and legal cosmopolitanism on domestic criminal proceedings present further challenges, and opportunities for insight, in theoretical modelling.

Many of these models of criminal process have demonstrated their heuristic value through longevity and myriad insightful applications, and most of them have something interesting to say about some aspect of criminal process, be it ever so local and temporally circumscribed. Models, to some extent, come in and go out of fashion with the times. Crucially, there is no reason to think that any single model must enjoy a unique or exclusive claim to wisdom and insight. Indeed, most—if not all—of the familiar models of criminal process tend to emphasise certain features of interest whilst downplaying or ignoring, and thus potentially obscuring, other significant features of criminal proceedings. For example, it might simultaneously be true (for any specified criminal justice process) that police stop and search is discriminatory as a practice and that defendants generally receive fair trials irrespective of ethnicity; or again, that criminal process is systematically class-biased and that working-class offenders generally receive their just deserts. To build up a lifelike portrait of this complex reality, in all its light and shade, will almost certainly require a range of theoretical models and methodological techniques rather than a single reductive pen-and-ink sketch.

It is in this methodologically pluralistic spirit that this book promotes 'integrity' as a timely, significant and powerfully illuminating, but as yet still largely untapped, conceptual resource for investigating and evaluating criminal process. The timeliness of integrity' derives from its increasing popularity with police, prosecution agencies, regulatory bodies and common law courts; and this institutional anchorage underscores its significance. 'Integrity' is not merely a scholar's or external critic's explanatory concept: it is also embedded in practitioners' discourses and has jurisprudential significance in positive law. Finally, the power of illumination we ascribe to 'integrity' is attributable to a combination of its resonance with extant legal categories and prevailing practices and its potential contributions to normative projects of critical jurisprudence and law reform. Integrity, in short, contributes an additional high-powered lens to the existing kaleidoscope of theoretical perspectives on criminal process.

The following chapters supply the proof of the pudding for this sweeping theoretical claim (or less ambitiously, will test our primary methodological hypothesis), by reconsidering afresh perennial topics and issues in the light of criminal process integrity. The essays are loosely organised according to the sequential logic of common law criminal

\footnotetext{
9 See eg J Jackson and S Summers, The Internationalisation of Criminal Evidence (Cambridge, Cambridge University Press, 2012); JJ Capowski, 'China’s Evidentiary and Procedural Reforms, the Federal Rules of Evidence, and the Harmonization of Civil and Common Law' (2012) 47 Texas International Law Journal 455; B Yin and P Duff, 'Criminal Procedure in Contemporary China: Socialist, Civilian or Traditional?' (2010) 59 International and Comparative Law Quarterly 1099; P Roberts, 'Comparative Criminal Justice Goes Global' (2008) 28 Oxford Journal of Legal Studies 369; M Delmas-Marty, 'Reflections on the "Hybridisation" of Criminal Procedure' in Jackson et al (eds), above n 5; JD Jackson, 'The Effect of Human Rights on Criminal Evidentiary Processes: Towards Convergence, Divergence or Realignment?' (2005) 68 Modern Law Review 737; M McConville and C Mirsky, 'Guilty Plea Courts: A Social Disciplinary Model of Criminal Justice’ (1995) 42 Social Problems 216; M King, The Framework of Criminal Justice (London, Croom Helm, 1981) ch 2.
} 
proceedings, starting with the initial phases of criminal investigation, interrogation of suspects and charging practice, prosecutorial discretion, pre-trial case preparation (including interviewing witnesses and instructing experts), plea-bargaining, trial procedure and evidence, verdict and judgment, and concluding with appeals and post-conviction remedies for miscarriages of justice. But the progression of ideas in the following pages is not entirely linear or confined within an (idealised) structural model of criminal process. Different strands of the theme of integrity are woven throughout each chapter's topical discussion, building up into a series of thematically related case studies in the integrity of criminal process. In bringing together discussions of Australian, British, Hong Kong and US criminal process, this volume should also be regarded as an extension of previous work and a further exemplar of 'common law comparativism. ${ }^{10}$

The tasks for this Introduction are, first, to supply a little more institutional context through a potted survey of recent 'integrity jurisprudence', and secondly, to offer, by way of initial orientation for explorers of unfamiliar territory, a working conceptual elucidation and taxonomy of integrity in criminal process, emphasising its dual character as (explanatory) theoretical heuristic and (normative) juristic ideal.

\section{Integrity Jurisprudence}

Integrity is not an entirely novel jurisprudential concept. Numerous nineteenth-century English cases invoke 'integrity' in relation to personal or professional honesty, ${ }^{11}$ good character ${ }^{12}$ or witness credibility. ${ }^{13}$ Intriguingly, one also finds early reported references to the 'justice and integrity' of courts and judges, ${ }^{14}$ the integrity of schemes of criminal penalties, ${ }^{15}$ and 'principles which do form part of the law, and which it is of the highest importance to maintain in their integrity.' ${ }^{16}$ References to 'integrity' in primary English legislation can be traced back, at least, to $1843 .{ }^{17}$ Further afield, judicial references to the integrity of legal proceedings appear as early as 1825 in Tasmania, within two decades of the founding of the grim Hobart penal colony. A little later we find a circuit judge extolling the importance of 'integrity' to jurymen at Bathurst Circuit Court, west of the Sydney penal colony. ${ }^{18}$ Nonetheless, integrity-talk appears to have increased dramatically in recent

${ }_{10}$ P Roberts and J Hunter (eds), Criminal Evidence and Human Rights (Oxford, Hart Publishing, 2012).

11 For example, Hunter $v$ Walters (1870) LR 11 Eq 292, 293 ('Ralph Walters was a person in whose integrity the highest confidence was placed by his clients'); Speight v Gaunt (1883) 9 AC 1, 6 (HL) ('The respondent had no reason to distrust either the professional capacity, or the solvency, or the integrity of Richard Ernest Cooke').

12 For example, Guardians of Halifax Union $v$ Wheelwright (1875) LR 10 Ex 183, 193 ('A confidence might be well placed in the integrity and character of some persons, which would not belong to any person entrusted with money').

${ }^{13}$ For example, Wright $v$ Sanderson (1884) 9 PD 149, 156 (CA) ('In the present case (as in others of the same kind) there is neither any suspicion of fraud nor any ground for calling in question the integrity of the witnesses').

${ }_{14} R v$ Almon (1765) Wilm 243, 256-57; 97 ER 94, 100; cited by Wills J in $R v$ Davies [1906] 1 KB 32, 40 (DC).

15 Jenks v Turpin (1884) 13 QBD 505, 521 (DC).

$16 R v$ Cox and Railton (1884) 14 QBD 153, 166 (CCR) (Grove J).

17 Public Notaries Act 1843, s 4 (concerning 'testimonials, certificates, or proofs as to the character, integrity, ability, and competency of any person who shall hereafter apply for admission or re-admission as a public notary').

18 Speech to Jury (2) [1841] NSWSupC 94; $R$ v Davidson [1841] NSWSupC 43. And see In re Tyler; $R v$ Rossi [1829] NSWSupC 25, (1828) NSW Sel Cas (Dowling) 568. 
years, both in volume and significance. It is striking, for example, that whereas Winfield's two 1921 volumes on abuse of legal procedure contained just one incidental mention of 'integrity, ${ }^{19}$ Andrew Choo's contemporary reconsideration of the topic founds the courts' inherent jurisdiction to stay criminal proceedings for abuse of process on a 'principle of legitimacy' cashed out in terms of 'protecting the moral integrity of the adjudicative process. ${ }^{20}$ Integrity's burgeoning jurisprudential significance is amply confirmed by rough quantitative snapshots from basic Westlaw searches. ${ }^{21}$ These data indicate that juridical discourses of integrity, at least in English and UK jurisprudence, are a predominantly late twentieth-century phenomenon, displaying exponential increases since about 1980 .

There is both more, and less, than semantics in the current popularity of juridical integrity. To some extent, 'integrity' might be invoked as a proxy, synonym or placeholder for other, familiar, procedural values such as 'fairness', 'due process', 'natural justice' or 'judicial legitimacy', the relative prominence of which has varied over time and between jurisdictions, partly_of course - as a reflection of the locally applicable doctrinal law. Pace Bentham's dogmatic insistence on factual rectitude, modern courts have always known that, " $\mathrm{t}$ ] ruth, like all other good things, may be loved unwisely—may be pursued too keenly-may cost too much, ${ }^{22}$ so that trade-offs must be made in adjudication between truth-finding and other normative considerations. One might say, adopting a broad view, that the judicial concern with procedural integrity begins with such trade-offs, whether or not the explicit terminology of 'integrity' is employed. Judicial decisions to admit, or exclude, improperly obtained evidence are one familiar context in which zero-sum conflicts between procedural values routinely arise in criminal trials. Despite some widely cited dicta extolling procedural fairness, ${ }^{23}$ English law during the twentieth century was largely characterised by a preference for admissibility over 'integrity'-inspired exclusion whenever evidential reliability could reasonably be assumed. (This also accounts for the partial exception of confession evidence, which could be excluded at common law when admissions were 'involuntary' and thus presumptively unreliable. $)^{24}$ Courts in Scotland, ${ }^{25}$ the Republic of Ireland, ${ }^{26}$

19 PH Winfield, History of Conspiracy and Abuse of Legal Procedures (Cambridge, Cambridge University Press, 1921) 171 (noting that if the practice of parties paying jurors were to become a 'common occurrence ... it would have an evil effect on the integrity of jurors in general').

20 AL-T Choo, Abuse of Process and Judicial Stays of Criminal Proceedings, 2nd edn (Oxford, Oxford University Press, 2008) 16. Also see P Roberts and A Zuckerman, Criminal Evidence, 2nd edn (Oxford, Oxford University Press, 2010) 22.

${ }^{21}$ A free-text word search for 'integrity' of the entire Westlaw UK database conducted on 8 January 2015 produced 8,655 'hits' for case law and another 1,097 for legislation. A total of 2,508 of these hits are categorised as relating to Criminal Law. Restricting the search parameters to pre-1 January 2000 mentions reduces the corresponding hits to 2,802 (case law), 269 (legislation) and 436 (crime). For the period up to 1 January 1980, hits further decrease to 1,400 (case law), 24 (legislation) and 122 (crime). For the entire century 1850-1950, the corresponding hits are 621 (case law), 2 (legislation) and 49 (crime); which is significantly fewer in all categories than for the last two years 1 January 2013 to 1 January 2015 (case law = 966; legislation = 251; crime = 341).

22 Pearse v Pearse (1846) 1 De G \& Sm 12, 28-29; 63 ER 950, 957.

${ }^{23}$ Notably including $R v$ Christie [1914] AC 545 (HL); Kuruma $v$ R [1955] AC 197, 204 (PC) (Lord Goddard CJ); and $R v$ Sang [1980] AC 402 (HL).

${ }^{24}$ Ibrahim v R [1914] AC 599, 609-10 (PC); P Mirfield, Confessions (London, Sweet \& Maxwell, 1985).

${ }^{25}$ Lawrie v Muir 1950 SLT 37; critically contextualised by P Duff, 'Irregularly Obtained Real Evidence: The Scottish Solution?' (2004) 8 International Journal of Evidence and Proof 77.

${ }_{26}$ People v O’Brien [1965] IR 142. Generally, see J Jackson, 'Human Rights, Constitutional Law and Exclusionary Safeguards in Ireland' in Roberts and Hunter (eds), above n 10. 
Australia, ${ }^{27}$ Canada $^{28}$ and the US federal jurisdiction ${ }^{29}$ have arguably been more receptive than English judges to arguments for rights- or values-based evidentiary exclusion, at least until recently. Differences in these broader institutional frameworks will necessarily condition the extent to which any linguistic turn to 'integrity' represents a substantial shift in judicial attitudes and criminal procedure law, rather than merely a change of nomenclature, in particular jurisdictions.

Even more closely than its natural affinity with evidentiary exclusion, judicial integritytalk is bound up with permanent stays of proceedings on the grounds of abuse of process. Although a tribunal's inherent jurisdiction to control abuses of its own process is a generic power, deriving from the core idea of a judicial proceeding under the rule of law, ${ }^{30}$ its development within common law criminal process has been particularly striking over the last several decades. In a 1991 forced rendition case, the South African Court of Appeal intervened to prevent an abuse of process 'so as to protect and promote the dignity and integrity of the judicial system. ${ }^{31}$ This judgment was cited by Lord Bridge several years later in what has become a leading authority on granting stays for abuse of process in several common law jurisdictions, $R v$ Horseferry Road Magistrates Court, ex parte Bennett. ${ }^{32}$ Albeit without propounding the concept of 'integrity' per se, Bennett famously declared that serious procedural irregularities might require legal proceedings to be stayed irrespective of their substantive merits, on the principled basis that 'the judiciary accept a responsibility for the maintenance of the rule of law that embraces a willingness to oversee executive action and to refuse to countenance behaviour that threatens either basic human rights or the rule of law. ${ }^{33}$ Two and half years later, Lord Steyn explicitly adopted the language of 'integrity' in considering the impact of alleged police entrapment on procedural propriety. ' $\mathrm{T}]$ he issue', his Lordship stated, 'is whether, despite the fact that a fair trial was possible, the judge ought to have stayed the criminal proceedings on broader considerations of the integrity of the criminal justice system. ${ }^{34}$

27 R v Ireland (1970) 126 CLR 321, 335; [1970] HCA 21 (Barwick CJ); Driscoll v R [1977] HCA 43; (1977) 137 CLR 517 (exclusion of a disputed unsigned confession); Bunning v Cross (1978) 141 CLR 54; [1978] HCA 22, [29] (Stephen and Aickin JJ). The common law was subsequently superseded by the Australian uniform Evidence Acts, s 138; see K Mellifont, Fruit of the Poisoned Tree: Evidence Derived from Illegally or Improperly Obtained Evidence (Annandale NSW, Federation Press, 2010).

${ }^{28}$ Collins $v$ R [2007] 1 SCR 350, (1987) 38 DLR (4th) 508, applying s 24(2) of the Constitution Act 1982. The Canadian Supreme Court subsequently disavowed Collins, holding that ' $\mathrm{t}] \mathrm{h}$ he phrase "bring the administration of justice into disrepute" must be understood in the long-term sense of maintaining the integrity of, and public confidence in, the justice system': $R v$ Grant [2009] 2 SCR 353, [68]. See further, Young, Chapter 1 in this volume.

29 Weeks $v$ US, 232 US 383 (1914); Mapp v Ohio, 367 US 643 (1961). The scope, and even the very existence, of the constitutional exclusionary rule have remained controversial in the USA. For a range of views, see eg RM Bloom and DH Fentin, "A More Majestic Conception": The Importance of Judicial Integrity in Preserving the Exclusionary Rule' (2010) 13 University of Pennsylvania Journal of Constitutional Law 47; TE Pettys, 'The Immoral Application of Exclusionary Rules' [2008] Wisconsin Law Review 463; G Calabresi, 'The Exclusionary Rule' (2003) 26 Harvard Journal of Law and Public Policy 111.

30 Connelly v DPP [1964] AC 1254 (HL); Mills v Cooper [1967] 2 QB 459, 467 (DC).

31 S v Ebrahim 1991 (2) SA 553, 582 (CA).

32 R $v$ Horseferry Road Magistrates' Court, ex parte Bennett [1994] 1 AC 42 (HL).

${ }^{33}$ Ibid 62 (Lord Griffiths). Cf Lord Oliver's reassertion, in dissent, of the traditional view that pre-trial abuses, 'whatever the degree of outrage or affront they may occasion', should be addressed through collateral civil or criminal law remedies rather than being 'thought to justify the assumption by a criminal court of a jurisdiction to terminate a properly instituted criminal process which it is its duty to try': ibid 73.

34 R v Latif [1996] 2 Cr App R 92, 101 (HL). 
Since these pioneering decisions of the mid 1990s judicial references to 'the integrity' of the criminal process have become commonplace. English appellate courts were soon expatiating on 'the integrity of police operations and public confidence in them'; $; 5$ 'the integrity of police evidence'; 36 'the integrity of the discovery process'; 37 'the integrity of an individual juror, and thus of the jury as a whole'; ${ }^{38}$ and 'confidence in the integrity of the sentencing or tariff-fixing process. ${ }^{39}$ In the unreported but publicly high-profile appeals in $R v$ Hickey (1997) — the case popularly known as the 'Bridgewater Four' — Roch LJ declared that 'the integrity of the criminal process is the most important consideration for courts which have to hear appeals against conviction. ${ }^{40}$ More recent case law is peppered with generalised references to 'the integrity of the trial process', ${ }^{41}$ 'the integrity of the administration of justice, ${ }^{42}$ 'the integrity of the criminal trial', ${ }^{3}$ and 'the integrity of the criminal justice system. ${ }^{44}$ Integrity-talk likewise features in judgments of the Scottish High Court of Justiciary ${ }^{45}$ and the Northern Ireland Court of Appeal. ${ }^{46}$ In Warren, a case in which the police had employed tracking and listening devices without first obtaining the necessary permissions for their use outside the jurisdiction, the Privy Council endorsed Choo's 'useful summary' of relevant jurisprudential principles, making the definitive issue 'whether the continuation of the proceedings would compromise the moral integrity of the criminal justice system to an unacceptable degree. ${ }^{47}$ Lord Kerr emphasised that ' $[t]$ he focus should always be on whether the stay is required in order to safeguard the integrity of the criminal justice system. ${ }^{48}$ In Maxwell, ${ }^{49}$ where the question before the courts was whether, following a successful appeal against conviction, a retrial could properly proceed in the light of revelations of serious misconduct and criminality by investigating officers, the UK Supreme Court mentions 'integrity' no fewer than 21 times. By a narrow three to two majority, the prosecution was allowed to proceed, but only on the basis of untainted evidence. Dissenting on the facts, Lord Collins stated emphatically that 'the interests of justice demand the application of the integrity principle..$^{50}$

Increasing judicial resort to the language of 'integrity' can also be observed across the wider Commonwealth. An early Canadian example is Rothman, ${ }^{51}$ where Justice Estey,

$35 R v$ Donald [1997] 2 Cr App R (S) 272, 275 (CA).

${ }^{36} R v$ Edwards (Maxine) [1996] 2 Cr App R 345, 349 (CA).

37 Taylor $v$ Serious Fraud Office [1998] EMLR 463, 478 (CA).

$38 R v$ Comerford [1998] 1 WLR 191, 195. Also see $R v$ Thorpe [1996] 1 Cr App R 269 (CA).

$39 R v$ Home Secretary ex parte Hindley [1998] QB 751, 770 (DC).

${ }^{40}$ Quoted approvingly in $R v$ Davis (Michael George) [2001] 1 Cr App R 8, [53] (CA).

${ }^{41} R v$ Farooqi [2014] 1 Cr App R 8, [2013] EWCA Crim 1649, [102]; R v Connors [2013] EWCA Crim 368, [33].

${ }^{42} R v C$ [2014] EWCA Crim 343, [6].

43 In re ITN [2014] 1 WLR 199, [2013] EWCA Crim 773, [10].

${ }^{44} R v$ Clayton [2014] 1 WLR 3994, [2014] EWCA Crim 103, [10].

45 For example, Barclay $v$ Richardson [2012] HCHAC 168 (integrity of investigations and prosecutions); Toal v HM Advocate [2012] HCJAC 123 (integrity of a jury's verdict); Telford $v$ HM Advocate [2012] HCJAC 88 (integrity of the court); Starrs $v$ Ruxton 2000 JC 208, [2000] HRLR 191.

46 For example, $R v$ McConville [2014] NICA 41; $R v$ McKeown [2004] NICA 41.

47 Warren v A-G for Jersey [2012] 1 AC 22, [2011] UKPC 10, [24]-[25]. Lord Dyson added that 'an infinite variety of cases can arise and how the discretion should be exercised will depend on the particular circumstances of the case'.

48 Ibid [83].

$49 R v$ Maxwell [2011] 1 WLR 1837, [2010] UKSC 48

${ }^{50}$ Ibid [115].

${ }^{51} R v$ Rothman [1981] 1 SCR 640. 
in dissent, linked the concept of integrity to the common law evidentiary rule excluding involuntary confessions from criminal trials. The 'basic reason for the rule', Justice Estey asserted, 'is a concern for the integrity of the criminal justice system', considering that the 'support and respect of the community for that system can only be maintained if persons in authority conduct themselves in a way that does not bring the administration of justice into disrepute. ${ }^{22}$ Since Rothman, integrity has been expansively woven into the Supreme Court of Canada's jurisprudence on constitutional rights and freedoms. It is now settled Canadian law that prosecutorial discretion can be reviewed where state officials' conduct is 'egregious and seriously compromises trial fairness and/or the integrity of the justice system. ${ }^{53}$ Recent cases expressly link 'the integrity' of criminal proceedings to, for example, access to pretrial custodial legal advice, ${ }^{54}$ the special responsibilities of prosecuting Crown Attorneys as 'ministers of justice,' ${ }^{55}$ procedural rules governing witness testimony, ${ }^{56}$ the evils of jury tampering, ${ }^{57}$ and the finality of adjudication. ${ }^{58}$ The Supreme Court of Canada has stated that " $\mathrm{t}]$ he integrity of our legal system depends in large measure on the integrity of those charged with its administration and enforcement. ${ }^{59}$ It has also-not unproblematically ${ }^{60}$ opined that ' $\mathrm{t}$ ] he decision to exclude evidence always represents a balance between the interests of truth on one side and the integrity of the judicial system on the other.'.

References to integrity in the jurisprudence of the High Court of Australia follow a similar pattern and trajectory, with dissenting judgments playing a pioneering role. In a 1979 case in which the trial court had refused to grant an adjournment to an unrepresented defendant, Justice Murphy was a lone voice in finding a substantial miscarriage of justice, on the basis that ' $[\mathrm{c}$ ] ourts should not allow the integrity of the judicial process to be undermined by the financial exigencies of legal aid schemes. ${ }^{2}$ In another dissent in Lowe a few years later, Justice Mason warned that 'inconsistency in punishment, because it is regarded as a badge of unfairness and unequal treatment under the law, is calculated to lead to an erosion of public confidence in the integrity of the administration of justice. ${ }^{63}$ Later, the integrity motif begins to surface and play a more significant role in majority opinions, doubtless reinforced by the courts' parallel development of a fair trial jurisprudence rooted

\footnotetext{
52 Ibid 658

$53 R v$ Anderson [2014] 2 SCR 167, [50]; $R$ v Nixon [2011] 2 SCR 566, [38], [64].

${ }^{54} R v$ Sinclair [2010] 2 SCR 310, [167]: '[I]t is also in society's interest that constitutional rights be respected at the pre-trial stage, as doing so ensures the integrity of the criminal process from start to finish'. See further, C Boyle and E Cunliffe, 'Right to Counsel During Custodial Interrogation in Canada: Not Keeping Up with the Common Law Joneses' in Roberts and Hunter (eds), above n 10.

${ }^{55} R v$ Regan [2002] 1 SCR 297, [151]: 'It is clear that Crown Attorneys perform an essential "Minister of Justice" role at all stages of their work. Their role in considering or carrying forward a prosecution is of the highest importance for the integrity of our criminal justice system ...'

${ }^{56} R v$ NS [2012] 3 SCR 726, [78].

57 R $v$ Yumnu [2012] 3 SCR 777, [38]: 'The mere thought of the Crown and the police "checking out" potential jurors carries with it the spectre of jury tampering and the evils associated with it. Care must be taken to guard against this. The integrity of our criminal justice system hangs in the balance.'

${ }^{58}$ R v Sipos [2014] SCC 47, [30]; R v Hay [2013] 3 SCR 394 [64] ('finality and order-values essential to the integrity of the criminal process').

${ }^{59} R v$ Beaudry [2007] 1 SCR 190, [113].

60 Because institutional integrity and truth-finding are not necessarily opposed.

${ }^{61} R v$ Buhay [2003] 1 SCR 631, [73].

$62 R v$ McInnis (1979) 143 CLR 575, [26].

${ }^{63}$ Lowe $v$ R (1984) 154 CLR 606, 611-12.
} 
in normative principles. ${ }^{64}$ For example, in Moti, where the majority found that the defendant's illegal deportation to Australia amounted to an abuse of process, the court emphasised 'the trust reposed constitutionally in the courts to protect the integrity and fairness of their processes'. ${ }^{65}$ In Smith $v$ Western Australia, the High Court recently averred that 'the first duty of the courts [is] to preserve the integrity of the system of criminal justice which they administer'. Serious allegations of juror misconduct were matters of prime judicial responsibility, because ' $[t]$ he institutional integrity of the system of justice is at stake in a way that is not the case where the issue is solely one between the parties. ${ }^{66}$

Similar references to the integrity of criminal process also feature in the jurisprudence of the New Zealand Supreme Court, which was established in 2004. In Hansen, for example, that Court observed that 'the presumption of innocence helps command the confidence of the general public in the integrity of the administration of the criminal law' ${ }^{67}$ More recently, in Siemer $v$ Solicitor-General, ${ }^{68}$ the New Zealand Supreme Court noted the conceptual and normative connections between institutional integrity and the (human) right to a fair trial, whilst in Wilson ${ }^{69}$ the Court was confronted with a catalogue of police impropriety (a falsely sworn search warrant, followed by a bogus prosecution and an attempt to implicate the Chief Judge of the District Court in an elaborate police ruse) which, the appellant submitted, would 'undermine the integrity of the justice system ${ }^{70}$ unless the proceedings were stayed. Although the appellant's convictions were quashed without any order for a re-trial, only Elias CJ concluded that the 'irremediably tainted' proceedings should have been stayed ${ }^{71}$ —an indication of the malleability and indeterminacy of appeals to 'integrity', which is another of this book's recurring themes.

Hong Kong courts have been debating similar issues in recent years, and likewise employing integrity-based arguments and concepts. In relation to the discretionary exclusion of unconstitutionally obtained evidence, the Hong Kong courts are charged with 'ensuring that the integrity of the judicial system is not compromised. ${ }^{72}$ In an earlier case, the Hong Kong Court of Final Appeal noted the legitimate 'public expectation that persons charged

\footnotetext{
64 See eg Dietrich $v R$ (1992) 177 CLR 292. Gaudron J, for example, affirmed that ' $\mathrm{t}$ ] he requirement of fairness is not only independent, it is intrinsic and inherent ... Thus, every judge in every criminal trial has all powers necessary or expedient to prevent unfairness in the trial': ibid 363-64.

${ }^{65} R v \operatorname{Moti}$ (2011) 245 CLR 456, [57].

66 Smith $v$ Western Australia [2014] HCA 3; (2014) 250 CLR 473, [45], [52]. See J Spigelman, 'Institutional Integrity and Public Law: An Address to the Judges of Hong Kong' (2014) 44 Hong Kong Law Journal 779.

${ }^{67} R v$ Hansen [2007] NZSC 7, [2007] 3 NZLR 1, [198].

68 Siemer $v$ Solicitor-General [2013] NZSC 68, [156]: 'The right to a fair trial is not only a fundamental right of an individual facing criminal proceedings; it is also essential to the administration of criminal justice and the integrity of the courts'.

${ }^{69}$ Wilson $v$ R [2015] NZSC 189.

70 Ibid [3]. Proceedings against the appellant's co-accused had already been stayed, on a finding by the trial judge that 'what the police did here is a fundamental and serious abuse of the court's processes': ibid [140]. These rulings were not challenged on appeal.

71 'The present case does not give rise to concern about fair trial. Rather, it is one where it is said that to hold a trial at all would be an affront to justice because the process is irremediably tainted by the undercover police operation which led to the charges. ... The salutary jurisdiction to stay proceedings is properly deployed only when the integrity of the criminal justice system would be compromised. ... What happened was inconsistent with minimum standards of criminal justice. To allow the trial to continue before a tribunal compromised in this way is a serious affront to the criminal justice system which required the exceptional course [of granting a stay]': ibid [124], [128], [153] (Elias CJ, concurring on disposal but dissenting in part from the majority's reasoning).

72 HKSAR v Muhammad Riaz Khan (2012) 15 HKCFAR 232, [18].
} 
with serious criminal offences will be brought to trial', but immediately added that, '[o]n the other hand, the Court must have regard to preserving the integrity of the criminal justice system. ${ }^{73}$

We do not purport to offer a comprehensive or systematic survey of increasing judicial resort to the concept of integrity in recent decades across the common law world. A great deal more might conceivably be said concerning ostensible patterns of usage and significance, their geographical spread, cross-jurisdictional influences, and noteworthy fluctuations-including shortfalls-in the currency of integrity. In Chapter 1 of this volume, Simon Young extends this preliminary exposition of integrity jurisprudence, drawing out its broader constitutional implications and significance for human rights, accountability, legitimacy and public confidence in the administration of criminal justice. Many further examples and illustrations of juridical integrity will be encountered in the following pages, embedded within contributors' discussions of particular criminal process issues, debates and developments. For now, by way of introduction, it is enough to have demonstrated that 'integrity jurisprudence' is a real, trans-jurisdictional phenomenon, which evidently merits careful scholarly scrutiny and critical evaluation.

\section{Juridical Integrity}

Further discussion might profitably begin with some semantic and conceptual clarification. The Oxford English Dictionary ${ }^{74}$ defines 'integrity' as, ' $[\mathrm{t}]$ he condition of having no part or element taken away or wanting; undivided or unbroken state; material wholeness, completeness, entirety ... The condition of not being marred or violated; unimpaired or uncorrupted condition; original perfect state; soundness'. And specifically in relation to moral integrity, ' $[\mathrm{s}]$ oundness of moral principle; the character of uncorrupted virtue, esp. in relation to truth and fair dealing; uprightness, honesty, sincerity'. Its Latin etymology anchors the concept of integrity in that which is whole and wholesome, unsullied, pristine.

As a normative value, integrity conveys the impression of being almost unequivocally laudable, right and good. Whereas most virtues (Aristotle taught us) ${ }^{75}$ tend to become vices when practised to excess, it is difficult to see how somebody could have too much integrity. Of course, there can always be competing considerations of prudence (think of Thomas More having too much integrity for his own—self-interested-good) or competing values potentially outweighing integrity in particular contexts, in the way that justice ought sometimes to be tempered by mercy. ${ }^{76}$ But it is not easy to think of obvious analogues for integrity of, say, over-generosity or foolish bravery or brutal honesty, where the tipping point

\footnotetext{
${ }^{73}$ HKSAR v Lee Ming Tee (2003) 6 HKCFAR 336, [187]. For detailed discussion, see Whitfort, Chapter 10 in this volume.

74 (Oxford, Oxford University Press, 2015), www.oed.com/.

75 'Virtue ... is a mean between two vices, that which depends on excess and that which depends on defect ... the vices respectively fall short of or exceed what is right in both passions and actions': Aristotle, The Nicomachean Ethics, trans D Ross (Oxford, Oxford University Press, 1998) 39.

76 See eg JG Murphy, Getting Even: Forgiveness and its Limits (New York, Oxford University Press, 2005); EL Muller, 'The Virtue of Mercy in Criminal Sentencing' (1993) 24 Seton Hall Law Review 288.
} 
to excess is internal to the value itself. (Fanatical integrity, perhaps?) Integrity is linked to authenticity, reliability, constancy, fair dealing and sound judgement. A person of integrity treats others in accordance with her deepest enduring convictions about how people ought to be treated; she is true to her values and true to herself. The sycophant and the gadfly as much as the hypocrite lack integrity. A person of integrity may be vulnerable to certain kinds of suasion or blackmail, but she is not easily corruptible. To say that everybody can be coerced or bullied if you can locate and exploit their human weaknesses is not the same as saying that 'every man has his price'.

It may be possible to characterise moral rigidity as an excess of integrity, as where 'the man of principle' is actually an insufferable holier-than-thou prig. That might be a fair criticism of those who ostentatiously stand on their honour and seek to inflate every contestable issue into a matter of principle. But it is not obvious why such a character flaw or its associated lapses of judgement should be regarded as symptoms of too much, rather than betraying too little, integrity. To be sure, to err is human, and to make a mistake-including a mistake about the requirements of morality—is not per se to lack integrity. But a prig is not merely in error. Utilitarians have been known to dismiss moral integrity as a kind of narcissistic vanity elevating personal conscience over the dictates of collective morality, but this objection arises from a thoroughgoing agent-neutrality with disturbing normative implications which few but card-carrying utilitarians are prepared to countenance. ${ }^{77}$

Part of the particular appeal of integrity is attributable to what might be described as its essentially 'procedural' character. Integrity can be distinguished from 'substantive' virtues like generosity, loyalty, honesty, or bravery, inasmuch as integrity is concerned with the way in which we relate to, think about, schedule, prioritise, and act on and through our other (substantive) values, whatever they happen to be. It follows that a person of integrity is not necessarily a good person. Bigots and brutal dictators are not necessarily lacking in personal integrity, whatever their other serious moral failings. So integrity shares this much with familiar juristic procedural values like 'natural justice' and 'due process': although they are plausibly regarded as intrinsic values in their own right, forming an irreducibly constitutive part of comprehensive accounts of justice, procedural values promote good outcomes only in conjunction with other, substantive values requiring independent normative justification.

Viewed in this way, there is an instructive parallel between integrity as a moral virtue and the second-order, superintending role played by practical reasonableness in theories of moral deliberation and practical action. ${ }^{78}$ Like practical reason, integrity is integrative with regard to our other values, both at the moment of deliberation or action and also, crucially, over time. Integrity has nothing to do with tunnel vision or bloody-mindedness. A person

\footnotetext{
77 See further, B Williams, Moral Luck (Cambridge, Cambridge University Press, 1981) ch 3; J Raz, The Morality of Freedom (Oxford, Clarendon Press, 1986) Part IV.

78 ' $[\mathrm{T}]$ he good of practical reasonableness has been explained as inner integrity and outer authenticity: authenticity in that one's actions carry out one's own choice that one made in line with one's own deliberations; integrity, in that one's emotions-passions - and sensibilities are integrated with one's reasons, judgments and choices': J Finnis, Reason in Action (Oxford, Oxford University Press, 2011) 14. See further, C Rovane, 'Rationality and Persons' in AR Mele and P Rawling (eds), The Oxford Handbook of Rationality (Oxford, Oxford University Press, 2004); J Raz, Engaging Reason (Oxford, Oxford University Press, 1999); N MacCormick, 'Contemporary Legal Philosophy: The Rediscovery of Practical Reason' (1983) 10 Journal of Law and Society 1; J Finnis, Natural Law and Natural Rights (Oxford, Clarendon Press, 1980) ch V.
} 
of integrity may well change her mind in response to new experiences or other pertinent information, even in relation to matters of fundamental moral significance to her. But a person of integrity does not blow hot and cold or mindlessly follow fashion. Just as a court should arrive at the same decision on the basis of the same evidence tomorrow or in a year's time as it does today (assuming no material change in the law), the person of integrity can be relied upon to embrace an enduring commitment to her convictions and practical judgements. Having made her bed, she lies in it without compunction or regret. The person of integrity is 'for all seasons', durable in any weather without losing her essential moral bearings or casting off her character-defining commitments before the prevailing winds of short-term pragmatism or social convention. Indeed, keeping faith with our past moral commitments and taking responsibility for our decisions and their future consequences is, in significant measure, what it means to be a person and to be the same person over time. We are experientially fully ourselves - we 'keep it together', colloquially speaking only when we are able to sustain both psychological and normative integration across space and time. ${ }^{79}$ Institutions claiming political authority_including policing, courts and legal systems - can analogously be thought of as having, or lacking, an integrated character and normative coherence over time.

It is tempting to think that substantive values are always, ceteris paribus, more important than 'mere' procedural considerations. But the simple equation of the procedural with the relatively less important is fallacious ${ }^{80}$ Procedural concepts and values like 'fair trial' or the presumption of innocence, for example, have far greater institutional purchase and symbolic resonance than many rules of substantive criminal law. And so it is that integrity is not merely a personal virtue of moral action. It is also an institutional virtue with especial significance for public institutions concerned with fair process and just outcomes. People might fervently wish - investing, perhaps, in hope over experience-for a world in which politicians behaved with integrity, but they positively demand this from their courts and judges and, more generally, from institutions administering justice and from the law itself. Law without integrity is capriciousness in robes, naked power without legitimacy. ${ }^{81}$ One might even argue, echoing Dworkin, that 'integrity' should replace 'justice-as-fairness' in Rawls' celebrated account of the first virtue of public institutions. ${ }^{82}$ Dworkin championed integrity as 'a distinct political ideal' ${ }^{83}$ providing the best interpretation of our existing practices of legislation and adjudication, 'best' in the two-fold sense that law-as-integrity aspires both to describe institutional practices accurately and simultaneously to supply their best normative justification. Dworkin's methodological turn to interpretivism ${ }^{84}$ was

\footnotetext{
79 See D Parfit, Reasons and Persons (Oxford, Clarendon Press, 1984) Part 3. Cf J Gray, Straw Dogs (London, Granta, 2002) 73, 76 (contending that ' [w] e act in the belief that we are all of one piece, but we are able to cope with things only because we are a succession of fragments. We cannot shake off the sense that we are enduring selves, and yet we know we are not ... We are hardwired for the illusion of self.')

${ }^{80}$ For one contextual elucidation of this argument, see P Roberts, 'The Priority of Procedure and the Neglect of Evidence and Proof: Facing Facts in International Criminal Law' (2015) 13 Journal of International Criminal Justice 479.

81 Or as Augustine more eloquently put it in his City of God (one-and-a-half millennia before a similar thought appealed to Karl Marx), Remota itaque iustitia, quid sunt regna nisi magna latrocinia?

82 'Justice is the first virtue of social institutions, as truth is of systems of thought': J Rawls, A Theory of Justice rvsd edn (Oxford, Oxford University Press, 1999) 3.

83 R Dworkin, Law's Empire (London, Fontana, 1986) 404.

${ }^{84}$ Ibid ch 2.
} 
intended to break the sterile impasse between 'legal positivist' and 'natural law' arguments in contemporary Anglo-American jurisprudence by transcending hackneyed contrasts between law as found and law as made, ${ }^{85}$ between law as it is and law as it ought to be. ${ }^{86}$ Dworkin insisted that:

Law's empire is defined by attitude, not territory or power or process ... It is an interpretive, selfreflective attitude addressed to politics in the broadest sense ... [T] he imperatives of integrity always challenge today's law with the possibilities of tomorrow's... every decision in a hard case is a vote for one of law's dreams. ${ }^{87}$

Setting aside for present purposes points of exegetical dispute and general debates about Dworkin's philosophy of law (which tend to elicit rather polarised reactions), ${ }^{88}$ the concept of integrity as a fundamental procedural value of law, legality and legal process seems both analytically illuminating and normatively appealing. Particularly as developed by Gerald Postema in his resonant evocation of 'justice in workclothes, ${ }^{89}$ integrity might be viewed as a fundamental value not only for legislators or appellate court judges deciding 'hard cases', but also as a primary normative resource, and commitment, informing the everyday conduct and decision-making of police detectives, prosecutors, defence lawyers, trial counsel, and first instance judges in criminal proceedings. Integrity, in other words, should be regarded as integral to legal professional ethics, informal occupational practices (especially those involving 'discretionary' decision-making), administrative rules and orders, codes of practice, and similar variations on the theme of 'soft-law' regulation or institutionalised 'working rules' ${ }^{90}$ materially affecting the conduct and influencing the outcomes of criminal investigations, prosecutions and trials. Or as Chief Justice Brennan of the Australian High Court once put it:

Integrity is the fidelity to legal duty ... It is the faithful adherence of the courts to the laws enacted by the Parliament, however undesirable the courts may think them to be, which is the guarantee of public confidence in the integrity of the judicial process and the protection of the courts' repute as the administrator of criminal justice. ${ }^{91}$

85 ' $[\mathrm{L}]$ aw as integrity rejects as unhelpful the ancient question whether judges find or invent law; we understand legal reasoning, it suggests, only by seeing the sense in which they do both and neither': ibid 225.

86 'Interpretivism ... denies that law and morals are wholly independent systems. It argues that law includes not only the specific rules enacted in accordance with the community's accepted practices but also the principles that provide the best moral justification for those enacted rules ... We must therefore do our best, within the constraints of interpretation, to make our country's fundamental law what our sense of justice would approve, not because we must sometimes compromise law with morality, but because that is exactly what the law, properly understood, itself requires': R Dworkin, Justice For Hedgehogs (Cambridge MA, Harvard University Press, 2011) 402,415 .

87 Dworkin, above n 83, 413, 410.

88 Dworkin seems like a man who, encountering jurisprudential trench warfare between positivists and naturalists, decided to set up camp in No Man's Land. He consequently attracted unfriendly fire from all directions, but also a small band of loyal lieutenants and disciples: generally, see S Guest, Ronald Dworkin, 3rd edn (Redwood City CA, Stanford University Press, 2013).

${ }^{89}$ GJ Postema, 'Integrity: Justice in Workclothes' (1997) 82 Iowa Law Review 821.

90 See eg A Sanders and R Young, 'From Suspect to Trial' in M Maguire, R Morgan and R Reiner (eds), The Oxford Handbook of Criminology, 5th edn (Oxford, Oxford University Press, 2012); M Stroshine, G Alpert and R Dunham, 'The Influence of "Working Rules" on Police Suspicion and Discretionary Decision Making' (2008) 11 Police Quarterly 315; K Hawkins, Law as Last Resort (Oxford, Oxford University Press, 2003); D Dixon, Law in Policing: Legal Regulation and Police Practices (Oxford, Oxford University Press, 1997); J Goldstein, 'Police Discretion Not to Invoke the Criminal Process: Low-Visibility Decisions in the Administration of Justice' (1960) 69 Yale Law Journal 543.

${ }^{91} R v$ Nicholas (1998) 193 CLR 173, [37]. 


\section{Integrity and Criminal Process}

Our preliminary efforts at definition and conceptual elucidation have established an intimate connection between integrity, as a primary institutional virtue, and theories of law, constitutional government under the rule of law, procedural justice, judicial responsibility and professional ethics. These relatively abstract connections are given more concrete, institutionalised, tangible form in the following pages. Each of this volume's essays might be thought of as a practical test bed for integrity's theoretical and methodological virtues in the context of criminal proceedings; or perhaps, as a collection of practice pieces embroidering justice's workclothes. Simon Young, in Chapter 1, further explores the conceptual parameters, historical development and doctrinal substance of integrity jurisprudence from a more overtly Public Law perspective. Young urges us to see that '[ $r$ ] ecognising criminal courts as public law courts, and their integrity as a prime consideration of public policy and political morality, ${ }^{92}$ opens up a broader range of public interest factors and remedial possibilities in the administration of criminal justice. The relationship between Public Law and Criminal Law features prominently in several other essays in the volume, especially those concerned with the powers, responsibilities and democratic accountability of public prosecutors. This is one, relatively localised manifestation of the book's appetite for interdisciplinarity which, in other contributions, embraces socio-legal research, policy studies, feminism, cognitive science, epistemology, narrative, ethics and political theory.

To suggest a more structured analytical framework, and by way of potted preview of the essays themselves, the remainder of this Introduction identifies four principal strands or facets of the complex relationship between integrity and criminal process, which together constitute the volume's unifying threads. There are also, of course, unresolved tensions, unanswered questions, and plenty of scope for sceptical appraisals of appeals to the integrity' of criminal process, in theory or in practice. The language of integrity, in professional discourses or policy pronouncements, must not become fatuous rhetoric or, worse, an ideological smokescreen cloaking its absence in reality.

\section{(a) Integrity as Fidelity to Advertised Normative Standards}

The most straightforward question that we might pose about the 'integrity' of criminal process is to ask whether, in practice, it lives up to its advertised principles and policies. Is there a seamless progression, or rather a disconcerting gap, between criminal process's normative ideals and policy commitments and their institutionalised practical realities? Implicit in this question is the need to specify the criminal process's authentic normative ideals; and this is likely to be a controversial, and possibly convoluted, undertaking. ${ }^{93}$ Any complex set of institutionalised human practices will fail to live up to its idealised

\footnotetext{
92 p 51, below.

93 For elucidation and illustrations, see P Roberts (ed), Theoretical Foundations of Criminal Trial Procedure (Farnham, Ashgate, 2014) Part II; A Duff, L Farmer, S Marshall and V Tadros, The Trial on Trial Volume Three: Towards a Normative Theory of the Criminal Trial (Oxford, Hart Publishing, 2007); HL Ho, A Philosophy of Evidence Law: Justice in the Search for Truth (Oxford, Oxford University Press, 2008).
} 
self-conception on occasion, just as wrongful conviction of the innocent is an occupational hazard of operating any criminal justice process. Isolated instances of human frailty should not be taken to constitute collective lapses of integrity (though they might well demonstrate failures of integrity on the part of the particular individuals concerned). However, repeated or systematic failures to live up to advertised standards raise justified suspicions of complacency, if not flagrant hypocrisy, suggesting that criminal process has no real intention of practicing what it preaches. Default in gross might properly be characterised as a failure of institutional integrity.

Julie Stubbs, in Chapter 2, poses this question in relation to the apparent failures of policing, over many years and across multiple legal jurisdictions, successfully to implement effective strategies to combat so-called 'domestic' violence. Feminist activism, criminological research data and official statistics accumulated over many decades converge on the conclusion that female victims of intimate violence are 'over-policed and under-protected' by criminal law. ${ }^{94}$ However, as Stubbs' comparative survey shows, the issues are complex. 'Pro-arrest' and 'no-drop' policies designed to improve enforcement come in several varieties, and they can fail or even backfire for various reasons. An interesting recent development is the novel use in domestic litigation of international human rights standards as a source of positive obligations on states to protect everyone, in equality, from lethal threats and serious harm..$^{95}$ Albeit an imaginative way of testing the sincerity of official policy commitments to tackling domestic violence, in court these arguments predictably run up against the common law's traditional deference to operational discretion in policing. ${ }^{96}$ A more fundamental objection is that more intensive state surveillance and extensive intervention, especially in the form of aggressive policing and criminal law enforcement, do not necessarily empower victims or treat suspects and offenders fairly. Stubbs calls for thoroughgoing reconsideration of how a polity might respond with integrity to the challenges and contradictions of domestic violence policing. This would seemingly require a victim-centred and holistic perspective, in which criminal law enforcement is only one strand of an integrated approach, buttressed by an intelligent division of institutional labour and effective inter-agency partnerships.

David Dixon's critical discussion of police interrogation tactics, in Chapter 3, exposes another potential gap between operational practice and the law's own advertised normative requirements-which in the two notorious murder cases he analyses in detail led to the inadmissibility of confessions procured in breach of the Police and Criminal Evidence Act (PACE) $1984 .{ }^{97}$ It is unnecessary to develop a sophisticated conceptual analysis to grasp the elementary point that police investigators sometimes break the procedural rules designed to regulate their conduct. The more interesting proposition emerging from Dixon's discussion

\footnotetext{
94 Symposium, 'Overpoliced and Underprotected: Women, Race, and Criminalization' (2012) 59(6) UCLA Law Review 1418; A Natapoff, 'Underenforcement' (2006) 75 Fordham Law Review 1715.

95 Generally, see L Lazarus, 'Positive Obligations and Criminal Justice: Duties to Protect or Coerce?' in L Zedner and JV Roberts (eds), Principles and Values in Criminal Law and Criminal Justice (Oxford, Oxford University Press, 2012); A Mowbray, The Development of Positive Obligations under the European Convention on Human Rights by the European Court of Human Rights (Oxford, Hart Publishing, 2004).

96 Van Colle v Chief Constable of Hertfordshire Police [2009] 1 AC 225, [2008] UKHL 50; Town of Castle Rock $v$ Gonzales, 545 US 748, 125 S Ct 2796 (2005).

97 See Roberts and Zuckerman, above n 20, ch 12.3; DJ Birch, 'The Pace Hots Up: Confessions and Confusions under the 1984 Act' [1989] Criminal Law Review 95.
} 
is that the rules themselves may be uncertain or contested. For example, the highly controversial 'Reid Technique' for interviewing criminal suspects widely embraced in the USA, and which seems to pervade police officers' questioning in some of the interview excerpts reproduced by Dixon in Chapter 3, is evidently in tension with English law's demands for non-oppressive interrogations and reliable confessions. ${ }^{98}$ But this theory of interrogation, directly or indirectly, reinforced British detectives in their existing investigative practices, which they believed to be lawful and legitimate; until the courts said otherwise. ${ }^{99}$ In such instances of normative ambiguity, competing claims to authority or conflicting loyalties, integrity serves as a prescriptive standard, or reasoning methodology, for reordering priorities and adjudicating 'hard cases' where there is something to be said on both sides of an argument. Similar normative ambiguities and operational dilemmas arise, for example, in relation to prosecutors' pre-trial interviews with witnesses (explored by Paul Roberts in Chapter 7), immunised accomplice testimony (reconsidered by Michael Jackson in Chapter 8 ) and the duties of prosecutors in adducing expert evidence (vigorously asserted by Gary Edmond in Chapter 9). Each chapter offers further illustrations of practical contexts in which integrity might afford criminal practitioners, policymakers and theorists greater direction and insight into their respective legal and ethical duties and practical objectives.

Contextual failures of integrity, in policy implementation or adherence to procedural law, might sometimes plausibly be regarded as sporadic and localised. They do not necessarily undermine the legitimacy of the entire adjudicative system. This is, however, precisely the dystopian scenario entertained by Mike McConville and Luke Marsh in Chapter 4. Their contribution to this volume develops an astonishing parallel between the indefensible practices of industrialised factory farming and a morally bankrupt criminal process corrupted by its addiction to pressurised guilty pleas. The analogy encompasses both process and product, to serve up (in either case) a distinctly unappetising dish. The implications are radical. Yet recent reforms of English criminal procedure, introduced against a backdrop of fiscal austerity, tend to reinforce rather than contradict their position. ${ }^{100}$

Writing from the perspective of a very experienced senior prosecutor, Nicholas Cowdery in Chapter 5 denies neither the inherent risks of accepting guilty pleas nor the institutional constraints and practical frustrations of criminal justice administration. He nonetheless maintains that pleas of guilty attracting sentencing discounts can in principle achieve just outcomes, at least where they are the product of a structured legal process (such as that in operation in New South Wales) rooted in prosecutorial independence, informed decision-making and appropriate consultation with interested parties. Justice through negotiation, on this fairly orthodox common law view, ${ }^{101}$ is not a contradiction in terms. Cowdery rightly insists on disaggregating the nebulous—and somewhat emotive-term 'plea bargaining'102 into the discreet institutional practices through which negotiated

98 PACE 1984, s 76(2).

$99 R v$ Paris, Abdullahi and Miller (1993) 97 Cr App R 99 (CA). Cf $R v$ Foster [2003] EWCA Crim 178.

100 M McConville and L Marsh, 'Adversarialism Goes West: Case Management in Criminal Courts' (2015) 19 International Journal of Evidence and Proof 172; J McEwan, 'From Adversarialism to Managerialism: Criminal Justice in Transition' (2011) 31 Legal Studies 519; A Edwards, 'The Other Leveson Report-The Review of Efficiency in Criminal Proceedings' [2015] Criminal Law Review 399; L Marsh, 'Leveson's Narrow Pursuit of Justice: Efficiency and Outcomes in the Criminal Process' (2016) 45 Common Law World Review 51.

101 For a civilian counterblast, see T Weigend, 'The Decay of the Inquisitorial Ideal: Plea Bargaining Invades German Criminal Procedure' in Jackson et al (eds), above n 5.

102 Cf N Vamos, 'Please Don’t Call it “Plea Bargaining”” [2009] Criminal Law Review 617. 
outcomes are actually secured in particular legal systems. Negotiations may focus on a range of variables (charges, facts, pleas) and be facilitated by widely differing procedures and incentives. Differentiated models of negotiated justice invite nuanced appraisal. Whilst the most plausible theoretical defences of guilty pleas tend to provide only qualified defences of existing institutional practices, ${ }^{103}$ Cowdery takes 'the actuality of criminal proceedings, in which compromise is an embedded fact of life, ${ }^{104}$ as his baseline assumption.

How might integrity inform these perennial debates? One of several methodologically instructive contrasts between these two chapters concerns the question of scale. McConville and Marsh address the 'guilty plea system' as a whole, whereas Cowdery is ultimately concerned with outcomes in particular cases (in a particular Australian state jurisdiction). Even on the pessimistic assumption that negotiated justice suffers from serious integrity deficits, where does that leave conscientious practitioners in individual cases? Should they resign or defect in protest? Or strive to secure just outcomes within the scope of their professional discretion? It would not follow from the fact that a justice system is broadly fair and legitimate that it always achieves just outcomes in every case. Conversely, particular guilty plea agreements might appropriately serve the ends of justice even in an adjudicative system ultimately lacking integrity. So it seems that, for our heuristic purposes, we should conceive integrity as a relative and scalar virtue of particular practical contexts, rather than only an all-or-nothing attribute of entire criminal processes (though it could be that as well). Systems, institutions, organisations, policies, practices and actors may exhibit more, or less, integrity at particular points in time. Integrity ideals, moreover, should inspire improvement without mocking feasibility, ${ }^{105}$ not least because in the domain of criminal justice choosing not to act or decide means abandoning victims of injustice to their fate. As the essays by McConville and Marsh and Cowdery both demonstrate in their different ways, intelligent normative appraisal of negotiated justice must be critical, ${ }^{106}$ informed, realistic and jurisdiction-specific; conducted, in other words, with intellectual integrity.

\section{(b) Institutional and Remedial Integrity as Normative Coherence}

A second interpretation of 'the integrity principle' employs the integrity-as-wholeness trope to consider whether a particular aspect of criminal process, or the administration of criminal justice viewed in its entirety, achieves an integrated holistic integrity. One might apply this analysis to the principal agencies of criminal proceedings-police, prosecution, judiciary, etc - or to particular aspects of their policy, function or practice. We might then ask, for example, whether the policing of domestic violence (discussed by Stubbs in Chapter 2) or interrogation policy and practice (Dixon's topic in Chapter 3 ) are coherent with the general values and policies of the police organisation. Or in relation to prosecutorial practice, we might try to assess the normative coherence of plea negotiation (Cowdery in Chapter 5), charging policy (Gans in Chapter 6), pre-trial witness interviewing (Roberts in Chapter 7),

\footnotetext{
103 See eg R Lippke, The Ethics of Plea Bargaining (Oxford, Oxford University Press, 2011).

104 p 121, below.

105 Cf P Pettit, 'Is Criminal Justice Politically Feasible?’ (2002) 5 Buffalo Criminal Law Review 427.

106 By which we mean open-minded, imaginative, courageous and unscandalised, rather than (expressly not) committed to any ideological programme.
} 
immunising accomplices (M Jackson in Chapter 8) or adducing expert witness testimony (Edmond in Chapter 9) with the advertised policies, standards and professional ethics of the organs of state prosecution. Criminal justice institutions and officials may lack integrity, not only in the first sense of failing to live up to advertised standards (hypocrisy), but alternatively (or also) in failing to present a unified and integrated normative vision across their various departments, functions and activities (incoherence).

The internal normative coherence of particular criminal process agencies, divisions or departments should be a matter of concern to policymakers and senior administrators within those agencies or departments. Coherence at this microscopic or 'local' level also equips researchers and scholars focusing on policing, prosecutions or the judiciary, etc with a critical standard for evaluating prevailing practices in each particular organisational setting. The heuristic potential of integrity is greatly amplified, however, when we consider the extent of normative coherence between different parts of the criminal process or in terms of the process as a whole. As with organs in the body or components of an engine, procedural integrity might be assessed piecemeal (examining each organ or component part separately), comparatively (considering two or more items together as a coherent package), or holistically, in terms of the overall health of the organism or the proper functioning of the machine.

Joanna Shapland once memorably characterised criminal proceedings as a sort of feudal economy, with each organ or agency jealously protecting its own jurisdiction and prerogatives largely in members' self-interest, leaving the disenfranchised peasants-complainants and witnesses - to fend for themselves. ${ }^{107}$ Although the role and status of victims in criminal proceedings has improved somewhat in the ensuing three decades, ${ }^{108}$ promoting effective inter-agency cooperation to achieve comprehensive criminal justice goals remains a central, and somewhat elusive, objective of criminal justice policymaking (as Stubbs also observes in relation to domestic violence policing in Chapter 2). To what extent, then, does procedural integrity as normative coherence presuppose effective collaboration and coordination between independent agencies and organisations in the criminal process neighbourhood?

The institutional integrity of criminal process is a complex idea. It implies neither frictionless normative coherence nor perfect institutional harmony on a day-to-day basis. Particularly within an adversarial procedural system premised on vigorous defence, excessively cosy relationships between criminal practitioners might themselves be a form of corruption betraying a lack of institutional integrity. ${ }^{109}$ Even in less avowedly adversarial procedural systems, however, relationships between professionals representing different parts of the process should be characterised by mutual respect for each other's functionally

\footnotetext{
107 J Shapland, 'Fiefs and Peasants: Accomplishing Change for Victims in the Criminal Justice System' in M Maguire and J Pointing (eds), Victims of Crime: A New Deal? (Buckingham, Open University Press, 1988).

${ }_{108}$ C Hoyle, 'Victims, the Criminal Process, and Restorative Justice' in M Maguire, R Morgan and R Reiner (eds), The Oxford Handbook of Criminology, 5th edn (Oxford, Oxford University Press, 2012); M Hall, 'Victims in the Criminal Justice Process' in A Hucklesby and A Wahidin (eds), Criminal Justice, 2nd edn (Oxford, Oxford University Press, 2013).

109 Not a new worry: see AS Blumberg, 'The Practice of Law as Confidence Game: Organizational Cooptation of a Profession' (1967) 1(2) Law \& Society Review 15; D Sudnow, 'Normal Crimes: Sociological Features of the Penal Code in a Public Defender Office' (1965) 12 Social Problems 255.
} 
differentiated roles rather than jovial collegiality, lest over-familiarity should breed a collusive contempt for distinct professional roles and responsibilities. ${ }^{110}$ Further complications arise from the hierarchical nature of some of these relationships. The Public Law principles elucidated by Young in Chapter 1 underpin the legitimacy of judicial review of administrative action as a concrete institutional expression of the Rule of Law. The principle of judicial review itself, albeit open to competing interpretations and varying degrees of intensity, ${ }^{111}$ is unexceptional in liberal political theory. But this still leaves plenty of scope for jurisdictional competition and vigorous debate at the level of practice.

The question of the proper scope of judicial review of criminal prosecutions is posed by Cowdery in Chapter 5. The starting point for any legal system respecting the accusatorial principle (that is, the functional separation of adjudication from prosecution, in contrast to the all-purpose medieval inquisitor or modern coroner) must be that prosecutors prosecute allegations of criminality and courts judge them; that notwithstanding the hierarchical seniority of the judiciary, the prosecutor is-as the Scots and civilians say-'master of the instance.. ${ }^{12}$ Of course, it does not follow from possession of an authentic original jurisdiction that prosecutorial decision-making involves completely unreviewable exercises of discretion. Cowdery shows, for example, that plea and charge negotiations in New South Wales are regulated by a principled set of standards and accompanied by procedural duties (including duties to consult with victims and police) which courts sometimes enforce, in the name of integrity. This discussion is extended in Chapter 6 through Jeremy Gans' detailed critical analysis of Australian and other common law authorities specifying the legitimate scope of judicial review of prosecutors' charging decisions. The topic is arcane, but not without intermittent media and public interest. ${ }^{113}$ The leading Australian authority is Maxwell, ${ }^{114}$ to which Gans administers a forensic hammering. The Australian High Court in Maxwell expressly invoked the 'integrity of the judicial process'115 as its motivation for restricting judicial interventions into prosecutors' charging decisions. Gans is unimpressed: partly because the Court seemed to have judicial self-interest at heart, but mainly becauseas Gans' extended analysis demonstrates-common law courts, whatever they might say, routinely employ a variety of doctrinal categories and strategies to constrain prosecutorial discretion, at least where the facts are capable of satisfying a range of overlapping offence definitions. Here, appeals to 'integrity' strike the discordant tone of empty judicial rhetoric.

Comprehensive conceptions of normative coherence imply what we might characterise as 'remedial integrity'. Injustice unremedied-justice delayed indefinitely-is a fortiori justice denied. In the service of integrity, criminal process should make appropriate institutional

\footnotetext{
${ }^{110}$ It is sometimes said that investigating judges, police and prosecutors in continental systems may become too friendly and end up working hand-in-glove: see eg J Hodgson, French Criminal Justice (Oxford, Hart Publishing, 2005) ch 7.

111 Anisminic v Foreign Compensation Commission [1969] 2 AC 147 (HL); cf Marbury v Madison, 1 Cranch 137, 5 US 137 (1803) (holding that 'a law repugnant to the constitution is void').

112 See eg Jude v HM Advocate [2011] UKSC 55, 2012 SLT 75, [17]. In private prosecutions, the complainant (Scots 'complainer') is master: HM Advocate v Caldwell 2010 SLT 1023, [2010] HCJAC 12, [12].

113 A high-profile decision not to pursue charges of child sex abuse recently prompted (misguided) calls for the DPP's resignation, for example: see R Greenslade, 'Most Newspapers call on Alison Saunders to resign as DPP', The Guardian, 30 June 2015 (blogpost); S O'Neill, 'Janner to be prosecuted amid calls for law chief's resignation', The Times, 29 June 2015.

114 Maxwell v R (1996) 184 CLR 501.

115 Ibid 534.
} 
provision for correcting the errors which are a foreseeable, and in aggregate unavoidable, consequence of human fallibility in the administration of justice. An obvious example is the provision for defence appeals against conviction or sentence, today widely recognised as integral to the fundamental right to fair trial, ${ }^{116}$ albeit a relatively recent innovation in the historical evolution of criminal adjudication. ${ }^{117}$ Remedial integrity must balance flexibility, rigour and accuracy in decision-making against the cost and finality of authoritative verdicts and judgments. It would hardly serve the ends of justice to allow appeals against appeals against appeals, and onwards to infinite regress. ${ }^{118}$ Nor can collateral challenges or 'satellite litigation' be permitted to spiral out of control and gobble up resources that could more profitably be devoted to other, more deserving causes. ${ }^{119}$ When criminal justice budgets are fixed, and indeed shrinking, remedial integrity is a zero-sum game.

Remedial integrity poses the question of the extent to which different parts of the criminal process may be held accountable for the errors or misbehaviour of other parts of the process, and for correcting their mistakes. One might think that responsibility is limited to direct institutional failings; that agencies and officials are accountable only for their own (mis)conduct without also having to answer vicariously for others' misdeeds. On this view, for example, the notion of a 'fair trial' refers only to what takes place in the courtroom, leaving alleged official improprieties or failings at earlier-or later-stages of criminal proceedings to be addressed through alternative procedural mechanisms and remedies. ${ }^{120}$ Alternatively, one might regard criminal proceedings as a single continuous process for which the state is ultimately responsible, notwithstanding liberal constitutional doctrines insisting on the separation of powers. This is the view encouraged by integrity as normative coherence. It suggests, for example, that gross impropriety in criminal investigations may so taint what comes later in the process that it is simply impossible, normatively speaking, for just punishment to be imposed on a guilty offender. The state, through its miscreant agents, has effectively forfeited its legitimate authority to judge and punish. The recent progress of integrity as an influential jurisprudential principle in many common law systems is chiefly attributable to a major shift in judicial thinking, from the first model of criminal adjudication in which balkanised institutional fiefdoms are allowed to proclaim 'we are not our brother's keeper', to the second model of collective institutional responsibility for the morality of criminal proceedings. ${ }^{121}$ The jurisprudential scaffolding for remedial integrity in criminal trials has mainly been supplied through developments of two traditional common law procedural mechanisms: the first, a rejuvenated doctrine of abuse of process, is described by Amanda Whitfort in Chapter 10; the second, evidentiary exclusion of improperly obtained evidence, is Peter Chau's topic in Chapter 11.

\footnotetext{
116 See eg ICCPR Article 14(5); S Trechsel with SJ Summers, Human Rights in Criminal Proceedings (Oxford, Oxford University Press, 2005) ch 14.

117 R Pattenden, English Criminal Appeals 1844-1994 (Oxford, Oxford University Press, 1996).

118 R Nobles and D Schiff, 'The Right to Appeal and Workable Systems of Justice' (2002) 65 Modern Law Review 676.

119 See eg $R$ v DPP ex parte Kebilene [2000] 2 AC 326 (HL).

120 As expressed, for example, in the juridical aphorism male captus, bene detentus: see United States $v$ AlvarezMachain, 504 US 655 (1992); P Michell, 'English-Speaking Justice: Evolving Responses to Transnational Forcible Abduction after Alvarez-Machain' (1996) 29 Cornell International Law Journal 383.

121 In particular, see $R v$ Horseferry Road Magistrates' Court, ex parte Bennett [1994] 1 AC 42 (HL); Teixeira de Castro v Portugal (1998) 28 EHRR 101; Roberts and Zuckerman, above n 20, 176-78.
} 
Whitfort surveys recent abuse of process jurisprudence in Hong Kong, Australia and the UK, drawing out several key points of continuity and comparison. Arguments over abuse of process have taken place in high profile cases, and produced a fair amount of dissonance between appellate courts' judgments and first instance rulings. Judicial decision-making in this context seems especially unpredictable and uncertain, even with regard to its underpinning rationales (for example, is disciplining the police ever a legitimate objective for a judge considering whether to impose a stay?) and operative legal tests. Whitfort helpfully draws together the main precepts that can be extracted from this evolving Commonwealth jurisprudence, but it is hard not to see in this 'principled guidance' a collection of rather disparate, open-ended, frequently rhetorical ${ }^{122}$ and completely indeterminate prescriptions lacking any strong internal coherence and ripe for judicial manipulation in concrete cases. Perhaps the jurisprudence is still underdeveloped at this stage; possibly, the psychological imperative of convicting serious offenders even where 'the constable has blundered' (or worse) will inevitably win out in the vast majority of disputes whatever the formal procedural rule is supposed to be. The need for general principles to be flexible enough to accommodate subtle variations in the material facts and circumstances of individual cases is also an important, sometimes overlooked or under-appreciated, constraint on the specification of procedural norms. ${ }^{123}$

Chau, in the following chapter, revisits the underlying rationales for excluding improperly obtained evidence from criminal trials. More specifically, Chau is concerned with nonconsequentialist rationales for exclusion, ie those that seek to justify exclusion on intrinsic rather than instrumental (typically epistemic) grounds. The evidence should be excluded, when it should, not because it is (probably) unreliable and may therefore lead to a factually incorrect determination, but for some other (non-consequentialist) reason. Judicially articulated rationales for exclusion embrace, and sometimes blend together, consequentialist and non-consequentialist (deontological) thinking. The motivation might be, for example, deterrence of future official misconduct, vindicating rights and remedying their breaches, serving the internal logic of procedural due process (or some aspect of it), or upholding the moral integrity of the proceedings and thereby preserving the legitimacy of trial verdicts. Although this is fairly well charted territory for Evidence scholars, ${ }^{124}$ Chau moves the debate forward in two significant respects. First, his terse recapitulation and juxtaposition of familiar arguments opens up established rationalisations to closer critical examination. Secondly, Chau draws attention to the relatively untapped potential of the idea of unjust enrichment as a source of non-consequentialist reasons for excluding improperly obtained evidence. His chapter presents an outline sketch of the 'no profit principle' as a rival or supplement to integrity-based exclusionary rationales. It is an imaginative proposal worthy of further elucidation and critical scrutiny.

122 Motiv R (2011) 245 CLR 456, [86] (Heydon J dissenting).

123 The complexity theme is developed in P Roberts, 'Excluding Evidence as Protecting Constitutional or Human Rights?' in L Zedner and JV Roberts (eds), Principles and Values in Criminal Law and Criminal Justice: Essays in Honour of Andrew Ashworth (Oxford, Oxford University Press, 2012).

124 See eg P Mirfield, Silence, Confessions and Improperly Obtained Evidence (Oxford, Clarendon Press, 1997); S Sharpe, Judicial Discretion and Criminal Investigation (London, Sweet \& Maxwell, 1998); R Pattenden, Judicial Discretion and Criminal Litigation, 2nd edn (Oxford, Clarendon Press, 1990) ch 7. 
What are the temporal limits of remedial integrity? Bitter experience of miscarriages of justice in recent decades — the latest chapters in a very long story ${ }^{125}$ —indicates why criminal verdicts cannot always be final even after the normal appeals process has run its course. In the book's concluding pair of essays, Charles Weisselberg and Carolyn Hoyle canvass issues bearing on the integrity of post-conviction procedures for dealing with alleged miscarriages of justice. Weisselberg, in Chapter 15, is concerned with the perils of emphasising 'actual innocence' in appeals against conviction. Of course it is not disputed that criminal proceedings should strive to protect the innocent from wrongful conviction. However, the extensive information marshalled by Weisselberg describing the activities of Innocence Projects, state commissions of inquiry and wider debates around miscarriages of justice and law reform in the USA ${ }^{126}$ highlights the risks associated with treating 'actual innocence' as the sole or predominant criterion for reviewing and, where necessary, remedying institutional failings. Over-concentration on factual innocence can lead to an excessively outcome-orientated instrumentalisation of criminal adjudication, which fails to address flawed or faulty official practices (treating the symptoms rather than the underlying causes) and marginalises process values of the type emphasised, for example, by Whitfort and Chau. It risks, in other words, systemic normative incoherence. Weisselberg explores these themes particularly in relation to unreliable confessions and the (disputed) practical significance of the US Supreme Court's iconic ruling in Miranda $v$ Arizona. ${ }^{127}$

In Chapter 16, Hoyle investigates persistent shortcomings in arrangements for providing state compensation to victims of miscarriages of justice. This is a topic with cosmopolitan resonance, ${ }^{128}$ which has also generated policy discussion and recent case law in England and Wales. ${ }^{129}$ By way of context, Hoyle reviews institutional developments stretching back to the creation of the Court of Criminal Appeal in 1907, but focussing more particularly on the work of the Criminal Cases Review Commission since $1997 .{ }^{130}$ She notes the formal distinction between 'not guilty' verdicts or quashed convictions following a successful appeal and positive declarations of innocence, and describes a handful of rare instances in which appellate courts went beyond their strictly legal remit and actually apologised to victims of miscarriages of justice. The problem, as Hoyle observes, with such doubtless wellmotivated but selective and very infrequent departures from the Court of Appeal's formal jurisdiction, is that there is a danger of creating de facto a two tier system of acquittals: 'first

125 See eg RC Huff and M Killias (eds), Wrongful Convictions and Miscarriages of Justice: Causes and Remedies in North American and European Criminal Justice Systems (New York, Routledge, 2013); BL Garrett, Convicting the Innocent: Where Criminal Prosecutions Go Wrong (Cambridge MA, Harvard University Press, 2012); R Nobles and D Schiff, Understanding Miscarriages of Justice (Oxford, Oxford University Press, 2000); J Rozenburg, 'Miscarriages of Justice' in E Stockdale and S Casale (eds), Criminal Justice Under Stress (London, Blackstone Press, 1992); K Carrington, M Dyer, R Hogg, J Bargen and A Lohrey (eds), Travesty! Miscarriages of Justice (Leichhardt NSW, Pluto Press, 1991); B Woffinden, Miscarriages of Justice (London, Hodder \& Stoughton, 1987); L Kennedy, Ten Rillington Place (London, Gollancz, 1961); Pattenden, above n 117, ch 1.

126 For UK debates, in addition to Hoyle, Chapter 16 in this volume, see M Naughton (ed), The Criminal Cases Review Commission: Hope for the Innocent? (Basingstoke, Palgrave, 2010); S Roberts and L Weathered, 'Assisting the Factually Innocent: The Contradictions and Compatibility of Innocence Projects and the Criminal Cases Review Commission' (2009) 29 Oxford Journal of Legal Studies 43; H Quirk, 'Identifying Miscarriages of Justice: Why Innocence in the UK is Not the Answer' (2007) 70 Modern Law Review 759.

127384 US 436 (1966).

128 Cf International Covenant on Civil and Political Rights, Art 14(6).

129 See, in particular, $R$ (Adams) $v$ Secretary of State for Justice [2012] 1 AC 48, [2011] UKSC 18.

130 The CCRC was created by the Criminal Appeal Act 1995, and became operational in 1997. 
class' acquittals of the truly innocent, and decidedly inferior acquittals of individuals who (to exaggerate only slightly) 'might well have been guilty but were given the benefit of the doubt or got off on a technicality'.

Applications for state compensation by those claiming to be victims of miscarriages of justice have crystallised this issue, because English courts and policymakers have always resisted the idea that compensation should be paid automatically to anybody whose conviction is finally quashed on appeal. What was formally an entirely discretionary ex gratia compensation scheme was subsequently placed on a statutory footing, and recent litigation has centred on the meaning of the statutory test for establishing eligibility for compensation. Hoyle retells the tale in detail. She is hostile to an 'actual innocence' standard, partly for the principled reasons advanced by Weisselberg in the preceding chapter, but also on pragmatic grounds. Whilst factual innocence may be difficult to ascertain reliably at the best of times, the Court of Appeal is a particularly unsuitable venue for attempting such determinations. The practical constraints, normative legal framework and forensic strategies of criminal appeals preclude, or at least strongly discourage, the presentation of evidence capable of proving actual innocence. Appellants rarely need to provide such information to succeed in their appeals. In this procedural environment 'actual innocence' would operate as an uncertain and quite possibly capricious standard. It would fail to meet threshold requirements of rationality in adjudication, ${ }^{131}$ and therefore lack integrity in the sense of cohering with an integrated scheme of basic values. Hoyle also canvasses a more local (and controversial) potential source of normative incoherence: are de facto second class ('not actually innocent') acquittals compatible with the presumption of innocence? Not on her account.

Without any pretence to comprehensiveness, the contributors to this volume range widely over the terrain of criminal investigations, prosecutions, trials, appeals and post-conviction remedies. We claim, and hope in the following pages to have demonstrated through numerous examples, that it is illuminating to consider whether existing law and practice in relation to any particular criminal process institution, phase, stage or functional operation is coherent, and at least in that sense has 'integrity', in its own terms and viewed holistically, as a constituent part of the administration of criminal justice. A police force that routinely accepted bribes to drop criminal charges whilst planting incriminating evidence on unforthcoming suspects would obviously lack integrity. But so, too, would charging practices that systematically failed to reflect the gravity of criminal wrongdoing, or a plea bargaining system incompatible with the presumption of innocence, or procedures for assessing demeanour at trial that resulted in discriminatory or unfair punishments being meted out to offenders. These aberrations do not necessarily involve departures from advertised policies or legal standards or exhibit the crasser forms of hypocrisy mentioned in the previous subsection. Rather, they suffer from a more profound normative incoherence, in being ultimately incompatible with a defensible conception of criminal justice. More localised incoherence is seen where a particular institutional policy, process or norm is self-defeating in its own terms. Anticipating John Jackson's argument in Chapter 12, it

131 See W Twining, 'The Rationalist Tradition of Evidence Scholarship' in E Campbell and L Waller (eds), Well and Truly Tried (Sydney, The Law Book Company, 1982); LL Fuller, 'The Forms and Limits of Adjudication' (1978) 92 Harvard Law Review 353; M Damaška, 'Rational and Irrational Proof Revisited' (1997) 5 Cardozo Journal of International and Comparative Law 25. 
would be irrational, for example, to insist on unreasoned jury verdicts in the name of preserving public confidence in criminal adjudication, if the failure to provide reasons came to be regarded as incompatible with the right to a fair trial and itself a source of widespread public criticism and dissatisfaction. The traditional practice would have shrivelled into a hollow husk, devoid of institutional integrity.

Promoting an ideal of integrity as 'normative coherence' does not deny the pervasiveness of competition between norms or the practical inevitability of jurisprudential loose ends and moral remainders. Perfect normative coherence is a Platonic chimera. Nor are we falling into the category error of thinking that questions of normative evaluation can be answered purely through methodological innovation or conceptual refinements. Value conflicts are an inherent, routine and-in gross ${ }^{132}$ —irremediable feature of criminal proceedings. Whether we are thinking about the tension between securing fair trials for the accused and appropriate concern and respect for victims and witnesses, or calculating the costs to truth-finding of excluding improperly obtained evidence, or calibrating the delicate balance between finality in adjudication and correcting miscarriages of justice, 'integrity' offers a heuristic for managing normative complexity rather than a whitewash for concealing its existence. In the following pages the reader will find many more illustrations of institutional moral dilemmas and tragic choices, where the righteous path of integrity may be circuitous, overgrown and difficult to discern and abide.

\section{(c) Epistemological Integrity: Evidence, Proof and Legal Narratives}

It is a minimum requirement for any plausible and normatively attractive conception of criminal adjudication that it should take fact-finding seriously; that it should strive, in other words, to convict the guilty but acquit the innocent. On traditional accounts, moreover, it is not acceptable to pursue more convictions of the guilty by creating disproportionately greater risks of wrongfully convicting the innocent. ${ }^{133}$ Orthodoxy in this regard has not gone unchallenged. ${ }^{134}$ However this normative balance might be struck, the rationality of proof and accurate fact-finding always ultimately rests on the integrity of the processes by which evidence is generated, collected, preserved, interpreted, packaged, presented, tested, challenged and, finally, evaluated by the fact-finder (and possibly re-evaluated during appeals and post-conviction procedures). The integrity of evidence is a third prominent theme of this book, reflecting-and more broadly contextualising—-professional legal discourse around preserving 'the continuity of evidence'135 and fidelity to truth in litigation. ${ }^{136}$

132 That is to say, some particular value conflicts may be remediable, but value conflicts tout court are not.

133 The traditional criminal standard of proof 'beyond reasonable doubt' is a keystone of the principled asymmetry of criminal adjudication: Roberts and Zuckerman, above n 20, ch 6.3. Also see eg A Volokh, ' $n$ Guilty Men' (1997) 146 University of Pennsylvania Law Review 173; S Sheppard, 'The Metamorphoses of Reasonable Doubt: How Changes in the Burden of Proof have Weakened the Presumption of Innocence' (2003) 78 Notre Dame Law Review 1165.

${ }^{134}$ Notably by L Laudan, Truth, Error and Criminal Law: An Essay in Legal Epistemology (Cambridge, Cambridge University Press, 2006).

135 See eg R (Byrne) v DPP [2003] EWHC 397 Admin; Paterson v DPP [1990] RTR 329; $R$ v $M$ [2001] EWCA Crim 2850, [15].

136 M Damaška, 'Truth in Adjudication' (1998) 49 Hastings Law Journal 289; S Haack, 'Of Truth, in Science and in Law' (2008) 73 Brooklyn Law Review 985. 
As before, it is easy to think of instances where the evidential process lacks integrity, including cases of deliberate tampering or perjury, and extending to cultured 'testilying' ${ }^{137}$ in all its shades and manifestations. However, as the essays in this volume show, preserving and authenticating the integrity of evidence-generating processes can be a subtle and multifaceted endeavour, demanding expertise and professional judgement. Judicial 'evidence' is properly conceptualised as a 'constructed' entity, in the sense of being an intentional product of human decision making, interactions and institutionalised processes. Whether we are thinking about police interrogation strategies (Dixon), or prosecutors interviewing complainants or other potential prosecution witnesses (Roberts) or negotiating with erstwhile accomplices to secure their testimonial cooperation (M Jackson), or the processes and practical routines for generating expert evidence (Edmond) - in each of these practical contexts, as well as in many others, evidence is a crafted artefact of its institutionalised production. Whether it is a carefully crafted product—and, indeed, what this nicely ambiguous phrase might mean and entail in practice-are contingent matters to be investigated, both at the aggregated level of routine procedures and with regard to particular cases.

Conceding the sociological truth of evidence 'construction' opens the way to nuanced (normative and descriptive) inquiries concerning the epistemological integrity of judicial evidence and proof. Are particular procedures, processes or practices truth-conducive, or alternatively, liable to frustrate forensic truth-finding? This is often a disputed question. Coercive police interrogation poses obvious risks of false confession, but aren't arrest, detention and interrogation inherently coercive? If so, why not disqualify all extrajudicial confessions as automatically inadmissible at trial? It is already settled practice in many common law jurisdictions for prosecutors to interview key witnesses as a routine aspect of thorough trial preparation. ${ }^{138}$ But if evidence is produced through interactions, is there not a risk that rehearsing a witness's evidence will change it? At what point does legitimate witness preparation become illegitimate 'coaching'? Paul Roberts explores these issues in Chapter 7, in the light of significant developments in English law and practice following the introduction of 'pre-trial witness interviews' (PTWI). ${ }^{139}$ And it goes without saying that doing deals with accomplices is an ethical minefield. Supping with the devil requires a long spoon. We should ask whether prosecutors' metaphorical cutlery is long enough to preserve the integrity of fact-finding, despite inviting courts to rely on the testimony of witnesses with such obvious incentives to lie, and who often possess insider-knowledge enabling them to do so effectively. ${ }^{140}$ Michael Jackson revisits these epistemic challenges and assesses institutional responses to them, from a Hong Kong perspective, in Chapter 8.

\footnotetext{
137 A redolent neologism reputedly coined by the New York Police Department to categorise testimonial lies about the manner in which evidence was procured in order to circumvent the Fourth Amendment exclusionary rule. See J Simon-Kerr, 'Systemic Lying' (2015) 56 William and Mary Law Review 2175.

138 See eg JS Applegate, 'Witness Preparation' (1989) 68 Texas Law Review 277; SV Vasiliev, 'From Liberal Extremity to Safe Mainstream? The Comparative Controversies of Witness Preparation in the United States' (2011) 9 International Commentary on Evidence, Article 5

139 P Roberts and C Saunders, 'Introducing Pre-Trial Witness Interviews-A Flexible New Fixture in the Crown Prosecutor's Toolkit' [2008] Criminal Law Review 831.

140 This worry is reflected in the common law's long-standing suspicion of accomplice testimony and witnesses with 'a purpose of their own to serve in giving evidence': $R v$ Beck [1982] 1 WLR 461, 466; $R v$ Spencer [1987] AC 128 (HL).
} 
Expert evidence introduces further epistemological complexities, which are tackled by Gary Edmond in Chapter 9. Law and Science can be conceptualised as alternative systems of practical epistemic authority, which can often be combined successfully (think about the power of DNA evidence or modern forensic medicine in contemporary criminal proceedings) but also sometimes compete in forensically problematic ways. ${ }^{141}$ Judicial reliance on science, through the medium of expert evidence, has a very long and somewhat chequered history in the common law. ${ }^{142}$ Edmond takes up the story of recent critical examinations of forensic science and forensic medicine, which have exposed the quite startling extent to which routine forensic procedures lack secure foundations in rigorous scientific method. ${ }^{143}$ More worryingly still, the traditional tools of adversarial trial, cross-examination and defence counter-expertise have patently failed to expose flaws and fallibilities in prosecution evidence, leading to miscarriages of justice. ${ }^{144}$ Having identified the true extent of the epistemological challenge for criminal adjudication presented by modern forensic science and forensic medical evidence, Edmond's essay draws out further institutional implications for the professional responsibilities of prosecutors, defence lawyers and courts.

In addition to considering the epistemological integrity of evidence and proof, we can also interrogate the integrity of broader criminal process narratives from an epistemological perspective. Symbolically and literally, criminal process tells culturally resonant 'stories' about crime and punishment. But are these true stories, or only convenient, media-friendly or fictionalised accounts, singing to the tune of powerful social interests rather than factual verisimilitude? For example, what kind of story do the no-drop policies discussed by Stubbs in Chapter 2 relate about domestic violence? The charging policies and plea negotiations examined by McConville and Marsh (Chapter 4), Cowdery (Chapter 5) and Gans (Chapter 6) play a vital role in framing the offence to be tried, ensuring (or not) that the punishment fits the crime in the event of a conviction. Whether or not narratives of crime and punishment generated by high volume guilty pleas retain epistemological integrity goes to the heart of disputes between critics and defenders of plea-bargaining. Are those pleading guilty actually guilty of the offence charged? To the extent that guilty pleas may be facilitated-or possibly dictated-by suspects' custodial confessions, the factual distortions potentially introduced by deficient police interrogation techniques, such as those criticised by Dixon in Chapter 3, are all the more troubling in this regard. Later in the progress of contested proceedings, judicial rulings on procedural submissions or the admissibility of evidence, such as those considered by Whitfort (Chapter 10) and Chau (Chapter 11), tell

141 For discussion, see P Roberts, 'Renegotiating Forensic Cultures: Between Law, Science and Criminal Justice' (2013) 44 Studies in the History and Philosophy of Biological and Biomedical Sciences 47; S Haack, 'Irreconcilable Differences? The Troubled Marriage of Science and Law' (2009) 72 Law and Contemporary Problems 1; AKY Wonder, 'Science and Law, A Marriage of Opposites' (1989) 29 Journal of the Forensic Science Society 75; CAG Jones, Expert Witnesses: Science, Medicine and the Practice of Law (Oxford, Oxford University Press, 1994).

${ }_{142}$ Generally, see P Roberts (ed), Expert Evidence and Scientific Proof in Criminal Trials (Farnham, Ashgate, 2014).

${ }^{143}$ See in particular, National Research Council, Strengthening Forensic Science in the United States: A Path Forward (Washington DC, National Academies Press, 2009).

${ }^{144}$ BL Garrett and PJ Neufeld, 'Invalid Forensic Science Testimony and Wrongful Convictions' (2009) 95 Virginia Law Review 1; E Beecher-Monas, 'Reality Bites: The Illusion of Science in Bite-Mark Evidence' (2009) 30 Cardozo Law Review 1369; SA Cole, 'The Prevalence and Potential Causes of Wrongful Conviction by Fingerprint Evidence' (2006) 37 Golden Gate University Law Review 39. 
their own stories about the values embedded in criminal adjudication, revealing judicial priorities when those values conflict or threaten the efficacy of criminal prosecutions.

A contested trial might be thought of as a kind of tournament of narratives, often vying against each other but sometimes proceeding in parallel or even in collaboration, for official recognition and authentication. A trial verdict is a narrative whose epistemic integrity is warranted by official endorsement. This legitimising relationship is contingent but, ideally, mutually reinforcing: the truth of the verdict is guaranteed by the integrity of the trial process, just as the integrity of the trial process is confirmed by the truth of its particularised verdicts. Conversely, the currency of criminal proceedings lacking integrity is false verdicts and miscarriages of justice. Although institutional details are partly a function of procedural tradition and will necessarily (and often harmlessly) vary across time and space, the manner in which verdicts and judgments are delivered and their detailed content will always be significant variables under the lens of epistemological integrity.

In Chapter 12, John Jackson revisits the question whether, in the modern era of human rights law, a growing expectation that important public decision-making should be explicitly reasoned and justified should be extended to impose associated obligations on the criminal trial jury. After all, formulating and publicising reasons for important decisions are widely regarded as minimal criteria of rationality and prime judicial responsibilities. Yet juries deliberate in secret and give no reasons to justify their determinations. ${ }^{145}$ This has generally been seen as an important guarantor of finality in verdicts, even by those with impeccable rationalist credentials. ${ }^{146}$ As Jackson describes, however, modern realities-both technological and juridical-seemingly call into question the extent to which tried-and-tested procedural approaches will be sufficient to sustain the legitimacy and public acceptability of unreasoned verdicts. Procedural innovation may be required to enable juries to live up to contemporary demands, underpinned by European human rights law, ${ }^{147}$ for transparency, rationality, fairness and accountability in their deliberations and verdicts. The implications for the integrity of criminal adjudication could hardly be more profound. Are juries on the traditional common law model capable of meeting novel expectations for a more 'judicial' style of decision-making? Which procedural changes are necessary, and how are they to be designed and implemented? Supposing that Jackson is right about the current direction of travel, will the model of criminal adjudication that emerges constitute a sensible and necessary development of our existing (and always evolving) procedural traditions, or a decisive break with the past heralding a new kind of 'jury verdict' for the twenty-first century?

In Chapter 13, Susan Bandes embarks upon a different kind of epistemological inquiry. Her topic is the role of remorse in criminal adjudication. This sounds like a normative issue for sentencing and punishment, and some of the material Bandes considers does indeed relate to the sentencing phases of US criminal trials, including death penalty hearings determined by juries. However, the methodological foundations of Bandes' discussion, which draws extensively on behavioural science and psychological research, are more

\footnotetext{
145 HL Ho, 'The Judicial Duty to Give Reasons' (2000) 20 Legal Studies 42; JD Jackson, 'Making Juries Accountable' (2002) 50 American Journal of Comparative Law 477.

146 JC Smith, 'Is Ignorance Bliss? Could Jury Trial Survive Investigation?' (1998) 38 Medicine, Science and the Law 98.

147 Cf P Roberts, 'Does Article 6 of the European Convention on Human Rights Require Reasoned Verdicts in Criminal Trials?’ (2011) 11 Human Rights Law Review 213.
} 
generic and far-reaching. By posing the question whether 'remorse' in the juridically relevant sense actually exists as a tangible practical emotion, Bandes opens up issues that are at once both conceptual and epistemological. How does one know when a convicted offender is (genuinely) remorseful? Since contrition in the courtroom must invariably be inferred from demeanour — with or without accompanying words of apology—infusing remorse with legal significance is vulnerable to similar behavioural science criticisms as can be made of orthodox legal rationales for inviting jurors to infer veracity and reliability, or their opposites, from witnesses' testimonial demeanour. ${ }^{148}$ This is especially problematic, as Bandes notes, where stereotypical or culturally blinkered expectations are liable to reinforce prejudice or unfair discrimination. But even where these particular concerns do not arise, legal procedures should be astute to ensure that findings of remorsefulness (or its absence) are epistemically well warranted; and that fact-finders' informal judgements of remorselessness (or other inappropriate or forensically damaging emotions) do not seep into verdicts and contaminate the integrity of criminal trials.

Having reviewed the relevant cognitive science literature, Bandes is sceptical about the robustness of evaluations of remorse in criminal trials, and this in turn leads her to recommend curtailing the influence of such shaky assessments on decision making in criminal adjudication, insofar as this is practically feasible. Normative arguments about the salience of remorse for questions of legal culpability, sentencing or punishment are idle, or in bad faith, unless 'remorse' can be defined and reliably identified, in the context of criminal prosecutions and trials, with epistemological integrity. This pattern of argumentation, underpinned by research in the cognitive and behavioural sciences, might be extended to challenge the epistemic integrity of legal fact-finding in relation to other emotions or practical attitudes associated with standards of criminal responsibility or criteria of aggravation or mitigation at sentencing. It also implies an interdisciplinary research programme for scholars with relevant skills and interests. ${ }^{149}$

Jill Hunter, in Chapter 14, likewise draws upon literatures outside the law to develop a counter-narrative to legal orthodoxy. The focus now shifts from first instance trials to appellate court judgments. In contrast to jury verdicts, which are the paradigmatic form of legal decision-making for Jackson and Bandes in the preceding two chapters, criminal appeals do, at least ostensibly, provide detailed rationalisations for their conclusions. Hunter's critical deconstruction of one judgment of the High Court of Australia ${ }^{150}$ grapples with multiple, intersecting narratives of contemporary doctrinal analysis, historical jurisprudence, and gender inequality, implicitly inviting further reflection on the range of audiences to which legal judgments—especially those delivered by constitutional or apex courts—might conceivably be addressed. Like Gans in Chapter 6, Hunter's discussion proceeds from what

148 See OG Wellborn III, 'Demeanor' (1991) 76 Cornell Law Review 1075; JA Blumenthal, 'A Wipe of the Hands, A Lick of the Lips: The Validity of Demeanor Evidence in Assessing Witness Credibility' (1993) 72 Nebraska Law Review 1157.

149 Generally, see eg DW Vick, 'Interdisciplinarity and the Discipline of Law' (2004) 31 Journal of Law and Society 163; C Menkel-Meadow, 'Taking Law and _ Really Seriously: Before, During and After "The Law”' (2007) 60 Vanderbilt Law Review 555; J McEwan, The Verdict of the Court: Passing Judgment in Law and Psychology (Oxford, Hart Publishing, 2003). But for words of methodological caution, see R Bagshaw, 'Behavioural Science Data in Evidence Teaching and Scholarship' in P Roberts and M Redmayne (eds), Innovations in Evidence and Proof (Oxford, Hart Publishing, 2007).

150 PGA v R (2012) 245 CLR 355, [2012] HCA 21. 
might initially appear to be a fairly technical doctrinal question, in the context of allegations of 'historic' sexual offending: was it a crime in 1963 for a man in South Australia to rape his wife? The majority of the High Court concluded it was, and Hunter does not directly contest the legitimacy of that conclusion. Her critique of the majority judgments centres on the arguments and information deployed to reach it, and the symbolic messages the judgment conveys to multiple audiences.

Specifically, Hunter argues that the High Court majority's resort to formalistic common law reasoning effectively airbrushes the true narrative of married women's lack of protection from sexual violence, in both substantive criminal law and prosecutorial practice (echoing a theme developed by Stubbs in Chapter 2); and that the Court was indefensibly recalcitrant to being better informed by readily available social scientific data indicating the realities of women's inequality before the law, extending far beyond the definitions of sexual offences and more recently in time than 1963. Just as the fairness of trials cannot be reduced to the accuracy of verdicts, Hunter's critical discussion demonstrates that the integrity of appellate judgment-writing is not simply a question of reaching the 'right' result. There are (even) bigger themes lurking here, pertaining to technology, democracy and the place of law in society. Within living memory, appellate court judgments were the preserve of dusty library bookshelves and technical interpretations by the legal priesthood. In the internet age, the pronouncements of appeal (especially apex) courts are now part of the law's immediately accessible public profile. This novel kind of exposure to 'the laity' inevitably brings with it new demands and expectations of judgment-writing with integrity, which courts cannot ignore if public confidence in the judiciary is to be maintained.

Provision for appeals and exceptional post-conviction review reflects the level of a particular legal system's commitment not only to correcting apparent factual errors, but also its willingness to contemplate fallibility in the first place and to facilitate proactive remedial measures in an effort to set the record straight. However, as Weisselberg shows in Chapter 15, focussing on unvarnished 'actual innocence' is not unproblematic for the administration of criminal justice, even if considered in purely epistemic terms. One reason for caution is that, by implicitly appearing to condone official illegality in order to uphold convictions of the guilty, truth-finding in future proceedings may be compromised (for example, because investigative practices eroding evidential reliability become routinised and unchallenged), even if factual accuracy is not undermined in the instant case. Further exploring the normative gap between 'acquittal' and 'innocence', in the volume's final chapter, Hoyle elucidates the narrative implications of denying monetary compensation to those whose convictions have been quashed following long sentences of imprisonment. How are we supposed to read the official truth of these cases, in which the prisoner is released and the conviction expunged, yet the courts still refuse to award compensation or even to issue an official apology?

Thinking about criminal process in terms of its epistemological integrity demands no less sophistication than trying to assess its adherence to advertised policy or prescriptive standards, modelling institutional coherence, or evaluating conformity with more comprehensive procedural ideals. 'Finding the truth' is far from a simple, reductive idea. ${ }^{151}$

\footnotetext{
151 See eg RP Burns, A Theory of the Trial (Princeton NJ, Princeton University Press, 1999) (elucidating a nonempiricist conception of legal fact-finding); AAS Zuckerman, 'Law, Fact or Justice?' (1986) 66 Boston University Law Review 487.
} 
Even at the granular level of individual pieces of evidence, the notion of evidential integrity is complex (though it can certainly be compromised in entirely prosaic ways), ${ }^{152}$ owing to the inherently constructed nature of judicial evidence and proof, the meshing of empirical and normative considerations, and the variety of institutional and social contexts in which facts are investigated, presented, disputed, evaluated and pronounced. When the analytical lens is widened to accommodate the plurality of competing and contested criminal process narratives, the adaptable concept of epistemological integrity can be deployed to illuminate the darker recesses of legal storytelling in, and about, proof, truth and fact-finding in criminal adjudication.

\section{(d) Personal and Professional Integrity}

In one tangible sense, the integrity of criminal process always comes down to the integrity of the professionals who operate it. Institutions, processes and procedures are not selfactuating, but rather represent an aggregation of human decision-making and concerted activity. Our fourth conception of criminal process integrity, as the personal and professional integrity of the men and women involved in the administration of criminal justice, might, then, just as easily have been our analytical point of departure.

The choices of individual police officers, ${ }^{153}$ prosecutors ${ }^{154}$ or even judges ${ }^{155}$ to take bribes, plant evidence or otherwise deliberately subvert the proper administration of justice are obvious failings of personal and professional integrity, which by extension also threaten the integrity of criminal process at large. Partly owing to the special responsibilities with which officials are entrusted, their wrongdoing may be difficult to detect or prove. This calls for robust institutional mechanisms for monitoring, deterring and exposing official corruption and other wrongdoing. It also demands effective institutional checks and balances, not only in terms of intelligent institutional design (addressed, in particular, by M Jackson in Chapter 8), but also in the sense that individual practitioners must rise to the challenge of

\footnotetext{
152 Physical contamination of forensic samples is one constant risk. For a striking illustration, see J Gans, 'Ozymandias on Trial: Wrongs and Rights in DNA Cases' in Roberts and Hunter (eds), above n 10.

153 Official policing policy in relation to corruption, and more broadly, increasingly invokes the ideal (or rhetoric) of 'integrity'. See eg HMIC, Police Integrity and Corruption Force Reports (2014), www.justiceinspectorates.gov.uk/hmic/publications/police-integrity-corruption-force/ (accessed 7 January 2016); Police Integrity Commission, Annual Report 2014-15 (Sydney, NSW PIC, 2015), www.pic.nsw.gov.au/Report.aspx?ReportId=165 (accessed 7 January 2016) (including discussion of 'integrity hazards'); Office of Police Integrity, Talking about Integrity: A Guide for Police Managers (Melbourne, OPI Victoria, 2009), www.ibac.vic.gov.au/docs/default-source/ guidelines/talking-about-integrity--a-guide-for-police-managers--apr-2009.pdf?sfvrsn=6 (accessed 7 January 2016); National Institute of Justice, 'Police Integrity', www.nij.gov/topics/law-enforcement/legitimacy/pages/ integrity.aspx (accessed 7 January 2016) (linking integrity to accountability, equal treatment, public accessibility, audit, and education of personnel); US Department of Justice, Police Integrity-Public Service with Honor, NCJ 163811 (Washington DC, Department of Justice, 2007); HMIC, Police Integrity: England, Wales and Northern Ireland - Securing and Maintaining Public Confidence (London, HMIC, 1999).

154 Ramanauskas v Lithuania (2010) 51 EHRR 11.

155 The UN Basic Principles on the Independence of the Judiciary, endorsed by GA Res 40/32 (29 November 1985) and GA Res 40/146 (13 December 1985), provide in paragraph [2] that judges 'shall decide matters before them impartially, on the basis of facts and in accordance with the law, without any restrictions, improper influences, inducements, pressures, threats or interferences, direct or indirect, from any quarter or for any reason'. Paragraph [10] further mandates that: 'Persons selected for judicial office shall be individuals of integrity and ability with appropriate training or qualifications in law.'
} 
discharging their designated institutional responsibilities skilfully and courageously. This applies, perforce, to the judicial responsibility to review the legality of all administrative action, a cornerstone of the rule of law in common law jurisdictions, as restated in general terms by Young in Chapter 1 and applied to judicial supervision of prosecutorial discretion by Cowdery (Chapter 5) and Gans (Chapter 6). Judicial willingness to visit illegality in the conduct of criminal investigations and prosecution with appropriate sanctions, including evidentiary exclusion, is another significant factor in this discussion, explored by Whitfort (Chapter 10) and Chau (Chapter 11), amongst others, in this volume.

This is not to say that institutional failings can always be laid wholly or directly at the door of individual miscreants. The conduct of criminal proceedings involves coordinated collective action. Individual practitioners operate within a framework of law, organisational policies and embedded routines and practices, which properly structure and constrain their individual preferences and judgements. Frontline practitioners may bear little personal responsibility for faithfully implementing their organisation's policies in accordance with its published objectives and priorities ${ }^{156}$ (though the same cannot necessarily be said for organisational leaders and their senior managers). Tensions between personal conviction and fidelity to professional duty may induce conflicts of loyalty, complicating the notion of acting with personal and professional integrity. This is a subplot of Hunter's critical discussion of judicial law-making in Chapter 14. Whistleblowers may be obliged to betray their friends and comrades in order to expose official wrongdoing. As Dixon cautions in Chapter 3, 'integrity' is not necessarily to be celebrated if it refers only to a self-defensive 'blue wall of silence' or, in broader terms, an impoverished criminal process committed to protecting 'its own' from external criticism and defending the existing social order at almost any cost.

It nonetheless remains an undeniable feature of criminal process that frontline officials retain significant spheres of personal operational discretion to exercise, as they deem fit, on a day-to-day basis. This is notoriously true of routine street policing, as ethnographers continually rediscover. ${ }^{157}$ In this volume, with its topical inclination towards litigated cases, it is prosecutorial discretion that looms particularly large, especially in the essays by Cowdery, Gans, Roberts and M Jackson (Chapters 5 to 8). Edmond, in Chapter 9, introduces the further complicating factor of expert witnesses' professional ethical responsibilities. ${ }^{158}$ An important methodological moral to be drawn from these discussions concerns the underappreciated theoretical significance of codes of professional ethics, alongside other 'soft

\footnotetext{
156 Assuming the 'normal' functioning of a broadly legitimate criminal process. Whether, for example, a judge in a racist legal system should resign or use their position to promote equality raises altogether different (existential) questions of personal and professional integrity: of D Dyzenhaus, Judging the Judges, Judging Ourselves (Oxford, Hart Publishing, 1998). On related questions of the integrity of positive law, see D Fraser, Law after Auschwitz: Towards a Jurisprudence of the Holocaust (Durham NC, Carolina Academic Press, 2005).

157 See eg CG Gerstein and JJ Prescott, 'Process Costs and Police Discretion' (2015) 128 Harvard Law Review Forum 268, 271-72 ('substantive law is mostly irrelevant to the matter of police discretion', referring specifically to minor public order offending); S Portillo and DS Rudes, 'Construction of Justice at the Street Level' (2014) 10 Annual Review of Law and Social Science 321; DA Harris, 'The Stories, the Statistics, and the Law: Why "Driving While Black" Matters' (1999) 84 Minnesota Law Review 265, 269, 319 (concluding that 'officers are free, for all practical purposes, to act on the assumption that being black increases the probability that an individual is a criminal', such that “"[d]riving while black" has begun to threaten the integrity of the entire process'). Generally, see D Dixon, Law in Policing (Oxford, Oxford University Press, 1997); R Reiner (ed), Policing II (Aldershot, Dartmouth, 1996).

158 Also see J Sanders, 'Expert Witness Ethics’ (2007) 76 Fordham Law Review 1539.
} 
law' instruments, for the conduct and supervision of criminal proceedings. Whilst primary legislation and appellate case law tend to dominate academic discussion and legal education, legal practitioners are often more directly concerned with codes of practice, internal guidelines, 'working rules' and local cultures of practice as normative resources structuring and guiding their discretionary decision-making. ${ }^{159}$

Professional legal ethics are too often assimilated to a list of mandatory directives for rote-learning by practitioners. Ethical practice should instead be conceptualised, and taught to practitioners, as a complex interface between abstract normative requirements and their concrete, contextualised applications, which professionals are obliged to negotiate for themselves under the aegis of integrity. ${ }^{160}$ Ethical legal practice is functionally differentiated, the more so in an adversarial procedural system. ${ }^{161}$ The duties of the prosecutor, as representative of the public interest and conscripted 'minister of justice' (see Cowdery in Chapter 5), are not coterminous with zealous representation of the accused, as Edmond (Chapter 9) also argues. Although none of our contributors affords systematic consideration to the ethics of criminal defence, the professional duties of defence lawyers crop up in relation to custodial police interviews with suspects (Dixon), negotiated pleas (McConville and Marsh), and adversarial challenges to expert evidence (Edmond). Concepts of professional integrity are further complicated by the appearance of criminal justice professionals embedded in alternative systems of practical authority and ethical responsibility. One thinks here of the forensic pathologist answerable to the dictates of medical ethics, as well as, more generally, of any expert witness committed to upholding scientific standards of validity, objectivity and non-partisanship. The integrity of criminal proceedings as a whole rests on the possibility of keeping potentially conflicting professional loyalties in productive tension, without allowing any one occupational group to dominate or to disrupt the normative equilibrium, but also without leaving any 'dead zones' in the coverage of professional responsibility. Circumstances of overlapping ethical duty can paradoxically conduce to ethical irresponsibility, as where everybody assumes (or too easily allows themselves to believe) that proactively managing the integrity of the process is ultimately'somebody else's business' whilst systemic failures in the meantime are 'not my fault'.

Critical discussion of personal integrity in criminal process is not exhausted by professionals' ethical obligations. Indeed, one might think that officials are really only the supporting cast. The primary actors in criminal proceedings are laypeople, in the guise of suspects, offenders, complainants, victims and witnesses. Do we expect even criminal defendants to play their designated role with integrity? In a sense, we do. After all, accused who elect to testify in their own defence take an oath (or affirm) to tell the truth under

\footnotetext{
159 In addition to citations at nn 90 and 157, above, see eg D Dixon 'The Normative Structure of Policing' in D Dixon (ed), A Culture of Corruption (Sydney, Hawkins Press, 1999); Pattenden, above n 124; MR Damaška, 'Structures of Authority and Comparative Criminal Procedure' (1975) 84 Yale Law Journal 480.

160 See further, AT Kronman, 'Living in the Law' (1987) 54 University of Chicago Law Review 835; WH Simon, 'Ethics, Professionalism, and Meaningful Work' (1997) 26 Hofstra Law Review 445.

161 See eg WH Simon 'The Ethics of Criminal Defense' (1993) 91 Michigan Law Review 1703. But cf TL Shaffer, 'The Unique, Novel, and Unsound Adversary Ethic' (1988) 41 Vanderbilt Law Review 697; AW Alschuler, 'How to Win the Trial of the Century: The Ethics of Lord Brougham and the OJ Simpson Defense Team' (1998) 29 McGeorge Law Review 291; HS Drinker, 'Some Remarks on Mr Curtis' "The Ethics of Advocacy"' (1952) 4 Stanford Law Review 349.
} 
sanction of perjury, ${ }^{162}$ theoretical though the threat of prosecution for advancing a lying defence may be in most cases. ${ }^{163}$ Even those who remain mute in the dock are expected to play their part, by entering a valid plea and standing their trial without disrupting the proceedings. ${ }^{164}$ These are admittedly rather minimalist standards of ethical propriety, and perhaps there is not a great deal more to be said about criminal defendants' integrity per se. Like lay witnesses of fact more generally, who are also often reluctant and sometimes unwilling conscripts in criminal proceedings, the duties of citizenship (at least as liberals generally conceive them) may be largely confined to turning up to court, speaking when spoken to, and telling the truth as the witness believes it. The fact that common law criminal trial procedure seems to have grown out of a pervasive distrust of witnesses ${ }^{165}$ tends to betray an institutionalised lack of confidence that even these minimalist reciprocal duties of citizenship will be discharged with integrity.

Is the position of complainants and victims any different in this regard to that of bystander witnesses? The prevailing view, bolstered by human rights law and several decades of victim-centred policy-making, ${ }^{166}$ is that it is, or at any rate ought to be. What, then, would integrity require of victims' participation in criminal proceedings, over and above every witness' duty to tell the truth? This is difficult terrain. One might reasonably expect enhanced rights of victim participation to be balanced by additional responsibilities. On the other hand, victims of crime are often emotionally vulnerable and are at risk of secondary victimisation through insensitive official processing. Perhaps the system itself should underwrite the integrity of their participation, at the same time as meeting their needs for support and information. Here, we can do no more than pose the question for further reflection and discussion.

Jurors are likewise conscripts to criminal proceedings, but in other respects represent a special case. Jurors are laypeople, but they also partly constitute the judicial tribunal and serve as the embodiment of the community in microcosm. The jury's special, indeed sacred, responsibility of judgment echoes down the centuries. ${ }^{167}$ It is plausible to think that the jury's pivotal role in a matter of such pre-eminent public importance as determining liability to criminal conviction and punishment might impose special responsibilities, even though jury service is mandatory for those selected. John Jackson pursues this line of

\footnotetext{
162 Intriguingly, this appears to be a cultural peculiarity of common law jurisdictions. Defendants do not testify under oath in civilian jurisdictions. See G van Kessel, 'European Perspectives on the Accused as a Source of Testimonial Evidence' (1998) 100 West Virginia Law Review 799; JK Walker, 'A Comparative Discussion of the Privilege Against Self-Incrimination' (1993) 14 New York Law School Journal of International and Comparative Law 1.

${ }_{163}$ Not in all cases: see eg $R v$ Miell [2008] 1 WLR 627, [2007] EWCA Crim 3130; DPP v Humphrys [1977] AC 1 (HL)

164 Disruptive accused are liable to be sent out of court, and may be held in contempt: see eg $R v$ McGrath [2013] EWCA Crim 1261, [2014] Crim LR 144; $R$ v Gough [2015] EWCA Crim 1079 (accused who 'held a sincere and deep belief in the philosophical approach to living life naked' and 'sought to live his life following his own reason and with integrity' was convicted in absentia, having insisted on appearing naked in court). Trials in absentia pose further challenges to the integrity of adversarial criminal adjudication: $\mathrm{cf} R v$ Gee [2012] SASCFC 86.

165 EJ Imwinkelried, 'The Worst Evidence Principle: The Best Hypothesis as to the Logical Structure of Evidence Law' (1992) 46 University of Miami Law Review 1069.

166 K Starmer, 'Human Rights, Victims and the Prosecution of Crime in the 21st Century' [2014] Criminal Law Review 777; J Doak, Victims' Rights, Human Rights and Criminal Justice (Oxford, Hart Publishing, 2008); JD Jackson, 'Justice for All: Putting Victims at the Heart of Criminal Justice?' (2003) 30 Journal of Law and Society 309.

167 JQ Whitman, The Origins of Reasonable Doubt: Theological Roots of the Criminal Trial (New Haven, Yale University Press, 2008).
} 
argument in Chapter 12, to reach conclusions challenging conventional wisdom. Criminal juries deliberate and decide collectively, but individual conscience plays an important role in the common law theory of jury trial, especially in North America where unanimous verdicts are still the norm and the 'hold out' juror is something of a cultural icon. ${ }^{168}$ Juries cannot be described as bearing 'professional' responsibility for their conduct in criminal trial proceedings, but the role of juror in a criminal case certainly does bring with it institutionally-defined as well as personal ethical responsibilities. For example, juries are required to deliberate in secret, and in England and Wales it is a contempt of court punishable by imprisonment to betray the secrets of the juryroom, even after proceedings are concluded. ${ }^{169}$ Still, ought implies can. Any existing or putative obligation on jurors to deliberate in a particular fashion, or to report the process or outcome of their deliberations in a particular way (with or without published 'reasons'), must be consistent with the (bounded) cognitive competence of human beings and the psychological dynamics of group decision-making. Personal and professional integrity is only a meaningful practical ideal whilst it remains on a human scale. It would be fatuous to criticise juries, or any other criminal process actors or agencies, for failing to live up to a supererogatory standard of integrity modelled on sainthood or superhuman cognition.

\section{Promoting Integrity}

The purpose of this book is to kick-start a methodologically sophisticated conversation about the 'integrity' of criminal process, and to make significant contributions towards its development across a range of familiar, and some less familiar, topics and issues. As befits an exploratory study of this nature, we make no pretentions to comprehensiveness, nor do we offer any firm conclusions in drawing this Introduction to a close. Having elucidated the concept of integrity and sketched out a preliminary taxonomy of criminal process applications, it is high time that we allowed the individual contributors to speak for themselves.

Some of the following chapters are primarily critically descriptive and diagnostic of shortcomings in contemporary criminal process. Others attempt to draw more programmatic lessons from deficient policies or practices, offering concrete proposals for procedural reforms calculated to promote integrity in criminal adjudication. Numerous pressure points, obscurities and blemishes in the evolving jurisprudence of integrity are identified along the way, informed by comparative legal scholarship. Integrity provides a methodologically well-appointed meeting place for vigorous, pluralistic debate encompassing a rich diversity of theoretical approaches and perspectives. Severally, and in collective synergy, the essays comprising this collection demonstrate both the heuristic value and the normative potential of refocusing criminal process through the lens of integrity.

\footnotetext{
168 An icon with complex cultural resonances, to be sure: see J Abramson, 'Anger at Angry Jurors' (2007) 82 Chicago-Kent Law Review 591.

${ }^{169}$ PR Ferguson, 'The Criminal Jury in England and Scotland: the Confidentiality Principle and the Investigation of Impropriety' (2006) 10 International Journal of Evidence and Proof 180; K Quinn, 'Jury Bias and the European Convention on Human Rights: A Well-Kept Secret?' [2004] Criminal Law Review 998.
} 